\title{
An Overview on the Photocatalytic Activity of Nano-Doped-TiO in the Degradation of Organic Pollutants
}

\author{
Yong Nian Tan, Chung Leng Wong, and Abdul Rahman Mohamed \\ School of Chemical Engineering, Universiti Sains Malaysia, Engineering Campus, Seri Ampangan, Seberang Perai Selatan, \\ Pulau Pinang, 14300 Nibong Tebal, Malaysia \\ Correspondence should be addressed to Abdul Rahman Mohamed, chrahman@eng.usm.my
}

Received 11 September 2011; Accepted 19 October 2011

Academic Editors: D. Chicot and P. Sánchez

Copyright (c) 2011 Yong Nian Tan et al. This is an open access article distributed under the Creative Commons Attribution License, which permits unrestricted use, distribution, and reproduction in any medium, provided the original work is properly cited.

This paper aims to review and summarize the recent works on the photocatalytic degradation of various organic pollutants in the presence of nano-doped- $\mathrm{TiO}_{2}$ photocatalysts. In this regard, three main aspects are examined: (a) the presence of various dopants (metal dopants, nonmetal dopants, halogen dopants, metalloid dopants, and codopants) in the formation of nano-doped-TiO ${ }_{2}$ photocatalysts, (b) the effect of the presence of dopants on the photocatalytic degradation of organic pollutants, and (c) the effects of various operating parameters on the photocatalytic degradation of organic pollutants in the presence of nano-doped-TiO ${ }_{2}$ photocatalysts. Reports resulted suggest that the formation of a high percentage of the anatase phase, small crystallite size, and high specific surface area of the nano-doped- $\mathrm{TiO}_{2}$ photocatalysts depends on the presence of various dopants in the photocatalysts. The majority of the dopants have the potential to improve the photocatalytic efficiency of nano-doped-TiO $\mathrm{O}_{2}$ in the degradation of organic pollutants. The photocatalytic degradation of organic compounds depends on the calcination temperature of the prepared doped $\mathrm{TiO}_{2}$, initial reactant concentration, dosage of doped $\mathrm{TiO}_{2}$, and dopant doping concentration.

\section{Introduction}

Water reuse has emerged as a critical issue in preserving global water resources in recent times. In many developing countries, industries contribute around $22 \%$ of the total world water usage and around $70 \%$ of untreated industrial wastes are simply discarded into wastewater without prior filtering or processing. The world faces enormous challenges ahead as drinkable water runs short due to natural disasters, population increase, and water pollution. To address these problems, advanced oxidation processes (AOPs) play an important role in the wastewater treatment. In AOPs, highly reactive radicals are generated that can treat the toxic and nondegradable pollutants in the wastewater efficiently without involving complex technologies [1].

The nano- $\mathrm{TiO}_{2}$ photocatalyst is a well-known photocatalyst among the metal oxides recognized for its high efficiency, low cost, physical and chemical stability, widespread availability, and noncorrosive property [2]. When nano- $\mathrm{TiO}_{2}$ is irradiated with ultraviolet (UV) light, electron is promoted from the valence band to the conduction band, resulting in the generation of energized "holes" in the former. Free electrons react with the oxygen to form superoxide radical anions $\left(\mathrm{O}_{2}{ }^{\bullet-}\right)$, while energized holes react with water $\left(\mathrm{H}_{2} \mathrm{O}\right)$ or hydroxyl ion $\left(\mathrm{OH}^{-}\right)$to form hydroxyl radicals $\left({ }^{\bullet} \mathrm{OH}\right)$. However, these reactive species are lost when the excited electrons and energized holes recombine without invoking a photocatalytic effect. Such electron-hole recombination diminishes the efficiency of photocatalysis.

To achieve high photocatalytic degradation efficiency, nano- $\mathrm{TiO}_{2}$ should be mesoporous and should exhibit high crystallinity and high specific area [3]. Nano- $\mathrm{TiO}_{2}$ is normally synthesized using various titania precursors such as titanium tetra-iso-propoxide (TTIP) [4], tetrabutyl titanate (TBOT) [5], titanium tetrachloride $\left(\mathrm{TiCl}_{4}\right)$ [6] besides other titanium compounds. Different starting materials can influence the morphology of the nano- $\mathrm{TiO}_{2}$ produced. For example, Verma et al. [7] reported that various types of alkoxy group in titanium alkoxide $\left(\mathrm{Ti}(\mathrm{OPr})_{4}\right.$ and $\left.\mathrm{Ti}\left(\mathrm{OPr}^{i}\right)_{4}\right)$ showed different properties of the mixed $\mathrm{CeO}_{2}-\mathrm{TiO}_{2}$ films. Zhang et al. [8] also stated that different types of starting 
materials of nano- $\mathrm{TiO}_{2}$ (titanium alkoxides and inorganic titanium, which are titanium sulfate and titanium chloride) could affect the properties of $\mathrm{TiO}_{2}$ /adsorbent nanostructured composites (TNC). Zhang et al. [8] found that chloride $\left(\mathrm{Cl}^{-}\right)$ions could promote the aggregation of titanium oxide species on the surface of activated carbon and the formation of the rutile $\mathrm{TiO}_{2}$ phase. On the other hand, the presence of sulfate $\left(\mathrm{SO}_{4}{ }^{2-}\right)$ ions could enhance the photocatalytic activity of nano- $\mathrm{TiO}_{2}$ [8]. At present, the effects of starting materials on the formation of nano- $\mathrm{TiO}_{2}$ have not been fully explored despite efforts that have been made to this end. Even though a complete understanding has yet to be achieved, it is generally accepted that titanium dioxide precursors affect the morphology of nano- $\mathrm{TiO}_{2}$ in aspects such as specific surface area, crystallinity phase, and crystallite size that play an important role in the photocatalytic degradation of organic pollutants [9].

It is clear from the literature that small crystallite size, high percentage of the anatase phase, and high specific surface area of nano-doped- $\mathrm{TiO}_{2}$ increase the photocatalytic degradation efficiency. For example, Venkatachalam et al. [10] found that the addition of magnesium nitrate during the formation of nano-doped- $\mathrm{TiO}_{2}$ by the sol-gel method promoted the exclusive formation of the anatase phase. The consequent enhanced adsorption of 4-chlorophenol over nano-doped- $\mathrm{TiO}_{2}$ and the decrease in particle size of nano-doped- $\mathrm{TiO}_{2}$ increased photocatalytic degradation of 4chlorophenol [10].

Doping techniques have been applied in photocatalysis to overcome the limitations of nano- $\mathrm{TiO}_{2}$, such as a wide band gap, ineffectiveness of photocatalysis under sunlight, and thermal instability $[8,11]$. Basically, nano- $\mathrm{TiO}_{2}$ can only utilize $6 \%$ of the total solar irradiation in photocatalysis due to the large band gap of anatase nano- $\mathrm{TiO}_{2}(3.2 \mathrm{eV})$, but doping techniques shift the activity of nano-doped$\mathrm{TiO}_{2}$ from the UV region to the visible light region [12]. This paper appraises different doping techniques [13] that widen the photocatalytic range from the ultraviolet to the visible light region, thus allowing for the photocatalytic degradation of organic pollutants under solar irradiation [14-17].

There are also negative effects of doping techniques in the photocatalytic performance of nano-doped-TiO 2 . Firstly, the dopant can act as a charge recombination center that acts against the separation of excited electron and hole. Secondly, doping techniques can inhibit the production of oxygen radicals in the photocatalysis reaction [18]. However, these problems can be countered by controlling the dosages of the dopants. Besides shifting the wavelength sensitivity of nanodoped- $\mathrm{TiO}_{2}$ into the visible light range, doping techniques can also improve the physical properties of $\mathrm{TiO}_{2}$. Cai et al. $[19,20]$ reported that suitable amounts of dopants helped to control the crystallite size of nano-doped- $\mathrm{TiO}_{2}$ while producing a high specific surface area of nano-doped- $\mathrm{TiO}_{2}$. A judicious rate of doping also prevented the transformation of the anatase phase to the rutile phase.

In this paper, studies on the modification of nano- $\mathrm{TiO}_{2}$ photocatalysts with various types of dopants are reviewed.
The photocatalytic activity of $\mathrm{TiO}_{2}$ incorporating various dopants doping processes on the photocatalytic degradation of organic pollutants are assessed. The effects of various operating parameters on the photocatalytic degradation of organic pollutants in the presence of nano-doped- $\mathrm{TiO}_{2}$ photocatalysts are also appraised.

\section{Short Background Regarding Photocatalytic Degradation Process}

According to Pirkanniemi and Sillanpää [21], the overall heterogeneous photocatalysis can be summarized into the following five steps: (1) reactant diffusion to catalyst surface, (2) adsorption of reactant onto the surface, (3) chemical reaction on the catalyst surface, (4) desorption of final products off the catalyst surface, and (5) diffusion of final products from the catalyst surface. Heterogeneous photocatalysis is a favorable combination of charge transport features, electronic structures, excited-state life spans, and light absorption effects. The basis of photocatalysis is the photo-excitation of a semiconductor that is solid as a result of the absorption of electromagnetic radiation, often, but not exclusively, in the near UV spectrum. When the energy (photon) supplied is equal to or greater than the band gap energy, $\Delta E_{g}$ of the photocatalyst, the excited electron in the valence band is transferred to the empty conduction band. (The band gap energy is the difference in energy between the valence band and conduction band of the photocatalyst. It is in the order of a few electron volts.) This leads to the generation of a positive hole $\left(h_{\mathrm{vb}}{ }^{+}\right)$in the valence band and an electron $\left(e_{\mathrm{cb}}{ }^{-}\right)$in the conduction band. As a result, electron-hole pairs are generated in the photocatalytic reaction

$$
\mathrm{TiO}_{2}+h_{v} \longrightarrow e_{\mathrm{cb}}{ }^{-}+h_{\mathrm{vb}}{ }^{+}
$$

where $h_{v}$ is energy required to transfer the excited electron from the valence band to the empty conduction band.

In this reaction, the positive hole and electron are powerful oxidizing and reducing agents, respectively. Generally, the positive hole reacts with either surface-bound water $\left(\mathrm{H}_{2} \mathrm{O}\right)$ or pollutant to produce hydroxyl radical $\left({ }^{\bullet} \mathrm{OH}\right)$ and surface adsorbed hydroxyl radical $\left({ }^{\bullet} \mathrm{OH} \mathrm{ad}\right)$.

$$
\begin{gathered}
h_{\mathrm{vb}}{ }^{+}+\mathrm{H}_{2} \mathrm{O} \longrightarrow \cdot \mathrm{OH}+\mathrm{H}^{+} \\
h_{\mathrm{vb}}{ }^{+}+\mathrm{OH}^{-} \longrightarrow{ }^{\bullet} \mathrm{OH}_{\mathrm{ad}}
\end{gathered}
$$

On the other hand, the electron in the conduction band is picked up by an electron acceptor such as oxygen to produce superoxide radical anion $\left(\mathrm{O}_{2}{ }^{--}\right)$.

$$
e_{\mathrm{cb}}^{-}+\mathrm{O}_{2} \longrightarrow \mathrm{O}_{2}^{\cdot-}
$$

Basically, the oxidative and reductive reactions do not occur concurrently. Hence, when an accretion of electron occurs in the conduction band, the electron is then recombined with the positive hole in the absence of the photocatalyst. As the photocatalytic reaction proceeds in preference to the positive hole-electron recombining, efficient electron 
consumption is hence essential to promote the photocatalytic oxidation. The equation of the recombination of positive hole and electron is shown below:

$$
e_{\mathrm{cb}}{ }^{-}+h_{\mathrm{vb}}{ }^{+} \longrightarrow \mathrm{TiO}_{2}
$$

Thus, the organic pollutant is oxidized to form salts, carbon dioxide, and water in the complete photocatalytic oxidation process.

$$
\cdot \mathrm{OH}+\text { pollutant }+\mathrm{O}_{2} \longrightarrow \text { products (salts, } \mathrm{CO}_{2}, \mathrm{H}_{2} \mathrm{O} \text { ) }
$$

\section{Effects of Dopants in the Formation of Nano-Doped-TiO 2}

Titanium dioxide is a well-known photocatalyst that is not only sensitive to light and corrosion resistant, but also inexpensive as an industrial material [22]. However, there are disadvantages linked to the use of $\mathrm{TiO}_{2}$ as a photocatalyst. These include the difficulty in producing highgrade $\mathrm{TiO}_{2}$ with tightly controlled physical properties and the fact that, in its basic form, it functions only under UV irradiation [23]. Many factors govern the physicalchemical properties of $\mathrm{TiO}_{2}$ during its production such as the speed of growth, the diffusion coefficient, and the ionic radii [24]. The method of preparation and posttreatment conditions also play prominent roles in synthesizing a high efficiency $\mathrm{TiO}_{2}$ product [25]. To overcome some of the difficulties encountered, different dopants (metal and non metal) are being investigated with the aim of enhancing the morphology of $\mathrm{TiO}_{2}$ in the photocatalysis [26].

Dopants modify the electronic structure of nano- $\mathrm{TiO}_{2}$ to broaden its effective range of light sensitivity for photocatalysis from the ultra-violet (UV) region to the visible light region [27]. Doping techniques have been shown to be effective and efficient despite their being susceptible to thermal instability and their requirement for expensive ionimplantation facilities [28]. Dopants are valued for their ability to confer excellent physicochemical properties such as high crystallinity (high percentage of anatase phase), high specific surface area, and small crystallite size $[20,29]$. There are three types of crystalline phases of nano- $-\mathrm{TiO}_{2}$, namely, the rutile, anatase, and brookite phases. The anatase and rutile phases are the common crystallographic phases found in the formation of nano- $\mathrm{TiO}_{2}$, with the former particularly favored for its high photocatalytic activity [30] and exceptional thermodynamic stability in nanoscale dimensions [9]. The crystalline structure of nano- $\mathrm{TiO}_{2}$ is represented as a $\mathrm{TiO}_{6}$ octahedral. The formation of the anatase and rutile phases or phase transformation from anatase to rutile is strongly dependent on the thermal dehydration process during which time; $\mathrm{Ti}-\mathrm{O}-\mathrm{Ti}$ bonds are formed by the interaction between $-\mathrm{OH}$ groups and the protonated surfaces.

Specific surface area of $\mathrm{TiO}_{2}$ is one of the factors that determine the morphology of $\mathrm{TiO}_{2}$ in photocatalysis. A large specific surface area of $\mathrm{TiO}_{2}$ enhances the photocatalytic degradation rate of organic pollutants as availability of active sites in $\mathrm{TiO}_{2}$ is increased [31, 32]. Crystallite size is another important characteristic that determines the quality of $\mathrm{TiO}_{2}$. The performance of nano- $\mathrm{TiO}_{2}$ can be enhanced in the photocatalysis by producing nano-doped$\mathrm{TiO}_{2}$ with high crystallite size up to a certain limit [33]. Thereafter, the photocatalytic performance of nano-doped$\mathrm{TiO}_{2}$ decreases when the crystallite size falls beyond this limit because of the trapping of charge carriers during the diffusion process. With the presence of dopants in the formation of nano-doped- $\mathrm{TiO}_{2}$, the phase transformation from anatase to rutile inhibits when the thermal energy is low enough to overcome the nucleation barrier during the thermal dehydration process, and this occurs more readily with the smaller crystallite size of nano-doped- $\mathrm{TiO}_{2}$ [34]. In short, dopants suppress the crystallite size of nano- $-\mathrm{TiO}_{2}$ by inserting itself into the lattice structure of the nano-doped$\mathrm{TiO}_{2}$ octahedral to modify its physicochemical properties. In general, a smaller crystallite size of nano-doped- $\mathrm{TiO}_{2}$ is favored compared to larger crystallite size of nano-doped$\mathrm{TiO}_{2}$ since the smaller size reduces the recombination of the photogenerated charge carriers [35]. Some researchers reported that smaller crystallite size of nano-doped- $\mathrm{TiO}_{2}$ induced a larger band gap due to the increased redox ability [31]. The resultant photocatalytic activity benefits from the quantum size effect of nano-doped- $\mathrm{TiO}_{2}$ that enhances its photocatalytic activity [32].

In another studies, some researchers found that the presence of dopants did not affect the morphology of nanodoped- $\mathrm{TiO}_{2}[36,37]$. For example, Nahar et al. [36] noted that Fe dopant, even at high concentrations, did not change the crystalline phase of nano-doped- $\mathrm{TiO}_{2}$. Li et al. [37] stated that cerium ions had no obvious effect on the particle size, morphology, and crystalline phase of nano-doped- $\mathrm{TiO}_{2}$.

Although nano-doped- $\mathrm{TiO}_{2}$ with large specific surface area, high percentage of anatase phase, and small crystallite size all contribute towards high photocatalytic activity, a complete understanding of the interlinkages between these variables has yet to be achieved and their detailed underlying mechanisms remain a challenge to researchers.

3.1. Effect of Metal Doping. Metal dopants have been used to improve the morphology and photocatalytic activity of nano-doped- $\mathrm{TiO}_{2}$. In previous studies, various metal dopants, including cobalt $(\mathrm{Co})[38,39]$, barium $(\mathrm{Ba})[40]$, manganese $(\mathrm{Mn})$ [41], nickel $(\mathrm{Ni})$ [42], copper $(\mathrm{Cu})$ [43], zinc $(\mathrm{Zn})[44]$, and iron $(\mathrm{Fe})[45,46]$, have been analyzed for their abilities to enhance the photocatalytic performance of nano-doped- $\mathrm{TiO}_{2}$. They improve nano-doped$\mathrm{TiO}_{2}$ performance under visible light irradiation by shifting the absorption spectra to a lower energy region [47]. In addition, various approaches have been attempted to sustain photocatalytic activity by limiting the recombination of the photogenerated electron-hole pairs in photocatalysis.

Hsieh et al. [38] produced codoped titania nanotubes with a specific surface area of $379 \mathrm{~m}^{2} / \mathrm{g}$, outer diameter of $10-15 \mathrm{~nm}$, and inner diameter of $5-10 \mathrm{~nm}$. Suriye et al. [39] found that codoped $\mathrm{TiO}_{2}$ exhibited high anatase phase based on X-ray diffraction (XRD) patterns. Smaller particle size of $\mathrm{Ba}$-doped $\mathrm{TiO}_{2}$ were synthesized by Atashfaraz et al. [40] who reacted titanium dioxide and barium hydroxide 
at high temperature in the flow reactor. Zhang et al. [41] produced $\mathrm{Mn}$-doped $\mathrm{TiO}_{2}$ using the sol gel method. Based on their observations, the band gap of the photocatalyst was narrowed due to the formation of an impurity level near the bottom of the conduction bands. Xu et al. [44] showed that $\mathrm{Zn}$ which was located on the titania nanotube surface had little effect on the titania nanotube morphology. Fedoped titania prepared by Janes et al. [45] using the sol gel method prevented the phase transformation of anatase to rutile at low dopant levels. The interaction was applicable to a maximum Fe dopant loading of $5.64 \mathrm{wt} \%$. Deng et al. [46] also investigated the morphology of Fe-doped titania nanotubes synthesized by the sol gel and hydrothermal methods. They found that the addition of Fe slowed the crystallization process and prevented the growth of crystallite $\mathrm{TiO}_{2}$.

Besides metal dopants, transition metals dopants such as palladium $(\mathrm{Pd})$, chromium $(\mathrm{Cr})$, and silver $(\mathrm{Ag})$ have been investigated by $\mathrm{Wu}$ et al. [48] to enhance the photocatalytic performance of nano-doped- $\mathrm{TiO}_{2}$. Among the transition metals dopants tested, Pd ion had the strongest interaction with nano- $\mathrm{TiO}_{2}$ and improved its morphology most effectively. Some researchers are of the opinion that doping techniques promote the production of smaller crystallite nano-doped- $\mathrm{TiO}_{2}$ with the resultant larger surface area helping to prevent the problem of particle agglomeration [49].

Among the metal dopants, $\mathrm{Fe}^{3+}$ ions reportedly benefit from uniform distribution into the lattice structure of $\mathrm{TiO}_{2}$ because of the similarity of their ionic radii [50]. $\mathrm{Fe}^{3+}$ ions are also thought to control the crystallite size of $\mathrm{TiO}_{2}$ and prevent the phase transformation of the anatase phase to the rutile phase. Deformation of the $\mathrm{TiO}_{2}$ crystal lattice occurs when $\mathrm{Fe}^{3+}$ ions $(0.690 \mathrm{~A})$ merge with $\mathrm{Ti}^{4+}$ ions $(0.745$ A), restricting the growth of $\mathrm{Fe}-\mathrm{TiO}_{2}$ crystallite size in the process.

$\mathrm{Fe}^{3+}$ ions have also been reported to act as shallow charge traps in the lattice of $\mathrm{TiO}_{2}$, and this accounts for its high photocatalytic activity [51]. This is explained by the conduction band edge of $\mathrm{TiO}_{2}$ being above the energy level for $\mathrm{Fe}^{3+} / \mathrm{Fe}^{2+}$, whereas the valence band edge of $\mathrm{TiO}_{2}$ is below the energy level for $\mathrm{Fe}^{3+} / \mathrm{Fe}^{4+}$ [49]. Hence, $\mathrm{Fe}^{3+}$ can react easily with the photogenerated electron (from conduction band of $\mathrm{TiO}_{2}$ ) and the hole (from valence band of $\mathrm{TiO}_{2}$ ) to form $\mathrm{Fe}^{2+}$ and $\mathrm{Fe}^{4+}$ ions. In this manner, $\mathrm{Fe}^{3+}$ ions can enhance the lifetime of the electrons and holes by acting as both electron and hole traps $\left(\mathrm{Fe}^{2+}\right.$ and $\mathrm{Fe}^{4+}$ ions). Nevertheless, $\mathrm{Fe}^{2+}$ and $\mathrm{Fe}^{4+}$ ions are not stable compared with $\mathrm{Fe}^{3+}$ ions due to the half-filled $3 \mathrm{~d}^{5}$ orbital.

The choice of different starting Fe materials affects the morphology of $\mathrm{TiO}_{2}$ that is produced. For instance, $\mathrm{FeCl}_{3}$ is widely used as a dopant because its $\mathrm{Cl}^{-}$ions are weakly bonded to the $\mathrm{TiO}_{2}$ surface as compared with $\mathrm{Fe}^{3+}$ ions. This facilitates the incorporation of $\mathrm{Fe}^{3+}$ ions, in preference over $\mathrm{Cl}^{-}$ions, onto the $\mathrm{TiO}_{2}$ surface. Consequently, Fedoped $\mathrm{TiO}_{2}$ with Brunauer-Emmett-Teller (BET) surface area of $100 \mathrm{~m}^{2} / \mathrm{g}$, crystallite size of $<9 \mathrm{~nm}$, and the presence of anatase phase can be obtained by adding less than $1 \mathrm{wt} \%$ Fe $[49,50,52-54]$.
Some of the researchers found that judicious doping with $\mathrm{Fe}$ improves $\mathrm{TiO}_{2}$ morphology, but specific surface area suffers beyond the optimum doping level [50, 52]. This is because Fe acts as a recombination center for both free electrons and energized holes [53, 54], thus limiting the interaction between $\mathrm{Fe}$ and $\mathrm{TiO}_{2}$ [49]. In addition, $\mathrm{Fe}$ induces the formation of amorphous titanium(IV)iron(III)-oxide that leads to the inhibition of the anatase phase of $\mathrm{TiO}_{2}$ [55]. The optimum Fe loading (0.007$1.200 \mathrm{wt} \%)$ gives a combination of crystallite size (9.0$23.7 \mathrm{~nm})$ and specific surface area $\left(55.5-175.0 \mathrm{~m}^{2} / \mathrm{g}\right)$ of $\mathrm{TiO}_{2}$ $[49,50,53-56]$.

The foregoing notwithstanding, there are other researchers who are of the view that the $\mathrm{Fe}$ is not requisite for the improvement of $\mathrm{TiO}_{2}$ characteristics. Li et al. [51] produced Fe-doped $\mathrm{TiO}_{2}$ with particle size of $10-15 \mathrm{~nm}$ via the hydrothermal method. They also reported that increasing the amount of Fe could narrow the band gap of $\mathrm{TiO}_{2}$ by shifting its activity from UV region to the visible light region. Based on an observation from X-ray photoelectron spectroscopy (XPS), Fe was thought not to be located on the $\mathrm{TiO}_{2}$ surface, but was positioned within the matrix interior. Thus, the isolated $\mathrm{Fe}^{3+}$ had a lower chance of transferring the trapped charge carriers to the interface and this could account for a decrease in photocatalytic activity, for example, in the degradation of methylene blue.

Sakthivel et al. [57] investigated the performance of $\mathrm{TiO}_{2}$ after supplementing with platinum $(\mathrm{Pt})$ dopant. Pt acted as an electron trap in the formation of $\mathrm{TiO}_{2}$, decreasing its surface area. While the generated free electrons gravitated towards Pt that served as a temporary electron trap preventing electron-energized hole recombination, increased $\mathrm{Pt}$ also competed with $\mathrm{TiO}_{2}$ as an electron trap to decrease effective surface area in the latter. A further increase in $\mathrm{Pt}$ dopant might lead to the following possible consequences: (1) shortening of the charge carrier space distance [57], (2) recombination of free electron and energized hole [58], (3) agglomeration of $\mathrm{Pt}$ and $\mathrm{TiO}_{2}$ [58], and (4) decrease in the probability of oxygen being photo-adsorbed on $\mathrm{TiO}_{2}$ [57]. The crystallite size of $9.15-31.00 \mathrm{~nm}$ and a specific surface area of $19.1-118.7 \mathrm{~m}^{2} / \mathrm{g}$ of $\mathrm{TiO}_{2}$ was produced by loading $\mathrm{Pt}$ at the rate of $0.1-1.5 \mathrm{wt} \%[56,58-61]$.

Chromium $(\mathrm{Cr})$, cerium $(\mathrm{Ce})$, and vanadium $(\mathrm{V})$ have also been used as dopants for $\mathrm{TiO}_{2}$. The addition of vanadium (V) increases the surface area and porosity of $\mathrm{TiO}_{2}$ [62]. The advantages of Ce as dopants include (1) decrease of the rate of crystallite growth, (2) promotion of mesoporous materials formation, (3) promotion of the stability of the active phase, (4) prevention of thermal loss in the catalyst area [63], and (5) prevention of the phase transformation of the anatase to the rutile phase [63].

Metal-doped $\mathrm{TiO}_{2}$ products reveal the presence of the anatase phase and a crystallite size of $\mathrm{TiO}_{2}$ ranging from 2.59 to $12.00 \mathrm{~nm}$. The specific surface area of $\mathrm{TiO}_{2}$ is in the region of $100-500 \mathrm{~m}^{2} / \mathrm{g}[49,50,52-60,62-66]$. Table 1 which summarizes the dopants used in $\mathrm{TiO}_{2}$ formation shows that different dopants are responsible for different structural properties of the $\mathrm{TiO}_{2}$. Further studies are needed to understand the mechanism of metal doping in the 
TABLE 1: Properties of metal-doped $\mathrm{TiO}_{2}$ photocatalysts under various conditions.

\begin{tabular}{|c|c|c|c|c|c|c|c|c|}
\hline $\begin{array}{l}\text { Type of } \\
\text { metal } \\
\text { dopant }\end{array}$ & $\begin{array}{l}(\text { Metal } \\
\text { dopant/TiO } \\
\text { molar ratio }\end{array}$ & Preparation of doped $\mathrm{TiO}_{2}$ & $\begin{array}{l}\text { Starting material } \\
\text { of } \mathrm{TiO}_{2}\end{array}$ & $\begin{array}{l}\text { Starting material } \\
\text { of metal dopants }\end{array}$ & $\begin{array}{l}\text { Crystallite } \\
\text { size }(\mathrm{nm})\end{array}$ & Phase & $\begin{array}{l}\text { BET } \\
\text { surface } \\
\text { area } \\
\left(\mathrm{m}^{2} / \mathrm{g}\right)\end{array}$ & Reference \\
\hline \multirow{6}{*}{$\mathrm{Fe}$} & 0.090 & Hydrothermal & TTB & $\mathrm{FeCl}_{3}, \mathrm{FeCl}_{2}$ & 11.40 & Anatase & 101.40 & {$[50]$} \\
\hline & 0.100 & Hydrothermal & $\left(\mathrm{Ti}\left(\mathrm{OC}_{4} \mathrm{H}_{9-n}\right)_{4}\right.$ & $\mathrm{Fe}\left(\mathrm{NO}_{3}\right)_{3} \bullet 9 \mathrm{H}_{2} \mathrm{O}$ & 14.50 & Anatase & 102.00 & {$[53]$} \\
\hline & 1.200 & Hydrothermal & $\mathrm{TiCl}_{3}$ & $\mathrm{FeCl}_{3} \bullet 6 \mathrm{H}_{2} \mathrm{O}$ & 23.70 & Anatase & 55.50 & {$[55]$} \\
\hline & 0.007 & Sol gel & TTIP & $\mathrm{Fe}\left(\mathrm{NO}_{3}\right)_{3}$ & - & Anatase & 175.00 & {$[54]$} \\
\hline & 0.700 & Sol gel/microemulsion & TTIP & $\mathrm{Fe}\left(\mathrm{NO}_{3}\right)_{3}$ & 12.70 & Anatase & 83.00 & {$[52]$} \\
\hline & 0.980 & Sol gel & $\mathrm{Ti}\left(\mathrm{OPr}^{\mathrm{i}}\right)_{4}$ & $\mathrm{Fe}\left(\mathrm{NO}_{3}\right)_{3} \bullet 9 \mathrm{H}_{2} \mathrm{O}$ & 9.00 & Anatase & 126.10 & {$[49]$} \\
\hline \multirow{5}{*}{$\mathrm{Pt}$} & 0.800 & Impregnation & $\begin{array}{l}\mathrm{TiO}_{2} \text { Degussa } \\
\text { P25 }\end{array}$ & $\mathrm{PtCl}_{2}$ & 22.28 & Anatase & 29.17 & {$[57]$} \\
\hline & 1.000 & Impregnation/Photodeposition & $\begin{array}{l}\mathrm{TiO}_{2} \text { Degussa } \\
\text { P25 }\end{array}$ & $\mathrm{H}_{2} \mathrm{PtCl}_{6}$ & 20.00 & Anatase & 107.00 & {$[64]$} \\
\hline & 1.500 & Impregnation & TTIP & $\mathrm{H}_{2} \mathrm{PtCl}_{6}$ & 31.00 & Anatase & 19.10 & {$[61]$} \\
\hline & 0.500 & Photochemical deposition & TBOT & $\mathrm{H}_{2} \mathrm{PtCl}_{6} \cdot 6 \mathrm{H}_{2} \mathrm{O}$ & 9.15 & Anatase & 116.10 & {$[60]$} \\
\hline & 1.500 & Photochemical reduction & TNBT & $\mathrm{H}_{2} \mathrm{PtCl}_{6} \cdot 6 \mathrm{H}_{2} \mathrm{O}$ & - & Anatase & 118.70 & {$[58]$} \\
\hline \multirow{3}{*}{$\mathrm{Ce}$} & 0.100 & Sol gel & $\mathrm{TiCl}_{4}$ & $\mathrm{H}_{2} \mathrm{PtCl}_{6} \cdot 6 \mathrm{H}_{2} \mathrm{O}$ & 14.00 & Anatase & 68.00 & {$[59]$} \\
\hline & 0.010 & Hydrothermal & $\mathrm{Ti}\left(\mathrm{SO}_{4}\right)_{2}$ & $\mathrm{Ce}\left(\mathrm{NO}_{3}\right)_{4}$ & - & Anatase & 454.00 & {$[63]$} \\
\hline & 4.000 & Reflux & $\mathrm{Ti}(\mathrm{OBu})_{4}$ & $\mathrm{Ce}\left(\mathrm{NO}_{3}\right)_{4}$ & 8.30 & Anatase & - & {$[65]$} \\
\hline $\mathrm{V}$ & 1.000 & Sol gel & $\mathrm{Ti}(\mathrm{OBu})_{4}$ & $\mathrm{VO}(\mathrm{OPr})_{3}$ & 12.00 & Anatase & 107.00 & {$[62]$} \\
\hline
\end{tabular}

formation of $\mathrm{TiO}_{2}$ and the influence of metal dopants in its morphology.

3.2. Effect of Nonmetal Doping. Various approaches have been made in the bid to hinder recombination of the photogenerated electron-hole pairs in nano- $\mathrm{TiO}_{2}$. Nonmetal anion doping has been exhaustively investigated because the electronic states of nonmetals are above the valence band edge of $\mathrm{TiO}_{2}$ compared with pure $\mathrm{TiO}_{2}$. Accordingly, different nonmetal dopants including carbon (C), nitrogen $(\mathrm{N})$, and sulfur (S) have been tested for their ability to improve the morphology and photocatalytic performance of $\mathrm{TiO}_{2}[73,74]$. The presence of nonmetal anions increases the percentage of the anatase phase in $\mathrm{TiO}_{2}$, restrains the growth of crystallite size of $\mathrm{TiO}_{2}$, and increases the specific surface area of $\mathrm{TiO}_{2}$ [75]. Besides, doping with nonmetal anions broadens the band gap of $\mathrm{TiO}_{2}$ in its electronic structure and affects the red-shift in the absorption spectra of nano-doped$\mathrm{TiO}_{2}$. In this way, various photocatalytic, photochemical, and the photoelectrochemical properties of $\mathrm{TiO}_{2}$ are enhanced by shifting the wavelength sensitivity of $\mathrm{TiO}_{2}$ from ultra violet region into the visible light region [73]. A summary of properties of various nonmetal dopants of $\mathrm{TiO}_{2}$ under various conditions is given in Table 2.

Phosphorus $(\mathrm{P})$ is used as a nonmetal dopant to enhance the thermal stability of $\mathrm{TiO}_{2}$ through the formation of titanyl phosphate [68]. In addition, $\mathrm{P}$ also improves the surface properties of $\mathrm{TiO}_{2}$ and reduces the oxygen vacancies, thus improving the performance of $\mathrm{TiO}_{2}$ in other applications such as photocatalysis and gas sensing [67]. High specific surface area of $154 \mathrm{~m}^{2} / \mathrm{g}$ and crystallite size of $8.6 \mathrm{~nm}$ of nano-doped- $\mathrm{TiO}_{2}$ have been successfully produced at a $\mathrm{P} / \mathrm{Ti}$ molar ratio of 0.14 [68]. Phosphorus doped $\mathrm{TiO}_{2}$ displays a larger specific surface area and smaller crystallite size as compared with pure titania [67].

Nitrogen $(\mathrm{N})$ has been reported to generate better dispersion, uniform particle size distribution, and uniform surface area when used to dope $\mathrm{TiO}_{2}$ in the hydrothermal process [76]. Senthilnathan and Phillip [70] obtained $22 \mathrm{~nm}$ of crystalline size of $\mathrm{N}$-doped $\mathrm{TiO}_{2}$. Nitrogen atoms substitute for the oxygen atoms in $\mathrm{TiO}_{2}$ lattice to form O-Ti-N. This substitution phenomenon is consistent with the findings of Peng et al. [69] who established $21 \%$ as the highest acceptable nitrogen dopant concentration in $\mathrm{N}-\mathrm{TiO}_{2}$.

Doping sulfur atoms into the $\mathrm{TiO}_{2}$ lattice improves the photocatalytic efficiency under visible light irradiation [72]. When fine crystalline $\mathrm{S}$-doped $\mathrm{TiO}_{2}$ was synthesized in the study of Ho et al. [72] through a simple hydrothermal method, the optical absorption of S-doped $\mathrm{TiO}_{2}$ in the visible light region increased in tandem with the increase in the $S$ content. This may be related to the finding by Tian et al. [71] that the anatase/rutile phase composition ratio was strongly influenced by the amount of $\mathrm{S}$. The phase composition ratio increased with the increase in $\mathrm{S}$ amount, with $\mathrm{TiO}_{2}$ doped with $1.5 \% \mathrm{~S}$ displaying the best crystallite size (around $30 \mathrm{~nm})$.

3.3. Effect of Metalloid and Halogen Doping. Halogen doping techniques have been made in the bid to hinder the transformation of anatase to rutile phase in nano-doped- $\mathrm{TiO}_{2}$ photocatalysts. The developments of halogen-doped $\mathrm{TiO}_{2}$ photocatalysts have attracted high attentions due to their ability in substituting into $\mathrm{TiO}_{2}$ matrix. Meanwhile, halogen doping could improve the surface properties as well as 
TABLe 2: Properties of non metal-doped $\mathrm{TiO}_{2}$ photocatalysts under various conditions.

\begin{tabular}{|c|c|c|c|c|c|c|c|c|}
\hline $\begin{array}{l}\text { Type of } \\
\text { non- } \\
\text { metal } \\
\text { dopant }\end{array}$ & $\begin{array}{l}(\text { Non metal } \\
\left.\text { dopant } / \mathrm{TiO}_{2}\right) \\
\text { molar ratio }\end{array}$ & $\begin{array}{l}\text { Doped } \mathrm{TiO}_{2} \\
\text { preparation method }\end{array}$ & $\begin{array}{l}\text { Starting } \\
\text { material of } \\
\mathrm{TiO}_{2}\end{array}$ & $\begin{array}{l}\text { Starting material } \\
\text { of non metal } \\
\text { dopants }\end{array}$ & $\begin{array}{l}\text { Particle } \\
\text { size }(\mathrm{nm})\end{array}$ & Phase & $\begin{array}{l}\text { BET } \\
\text { surface } \\
\text { area } \\
\left(\mathrm{m}^{2} / \mathrm{g}\right)\end{array}$ & Reference \\
\hline \multirow{2}{*}{$\mathrm{P}$} & 0.020 & Hydrothermal & TNBT & $\mathrm{H}_{3} \mathrm{PO}_{2}$ & 14.50 & Anatase & 104.00 & {$[67]$} \\
\hline & 0.140 & Sol gel & $\begin{array}{l}\mathrm{TiO}_{2} \text { Degussa } \\
\mathrm{P} 25\end{array}$ & $\mathrm{H}_{3} \mathrm{PO}_{4}$ & 8.60 & Anatase/rutile & 154.00 & {$[68]$} \\
\hline \multirow[t]{2}{*}{$\mathrm{N}$} & 0.265 & Hydrothermal & $\begin{array}{l}\mathrm{TiO}_{2} \text { Degussa } \\
\text { P25 }\end{array}$ & TEA & 15.40 & Anatase/rutile & - & [69] \\
\hline & 1.600 & Hydrothermal & TTIP & $\mathrm{CH}_{3} \mathrm{CH}_{2} \mathrm{NH}_{2}$ & 25.40 & Anatase & - & {$[70]$} \\
\hline \multirow{2}{*}{ S } & 1.500 & Hydrothermal & $\mathrm{TiCl}_{4}$ & $\mathrm{CS}\left(\mathrm{NH}_{2}\right)_{2}$ & 30.00 & Anatase & - & {$[71]$} \\
\hline & 2.800 & Hydrothermal & $\mathrm{TiS}_{2}$ & $\mathrm{TiS}_{2}$ & 2.80 & Anatase & - & {$[72]$} \\
\hline
\end{tabular}

the optical properties of $\mathrm{TiO}_{2}$ photocatalysts [77]. Accordingly, different halogen dopants including iodine (I), bromine $(\mathrm{Br})$, and fluorine $(\mathrm{F})$ have been investigated in order to improve the morphology and the photocatalytic performance of $\mathrm{TiO}_{2}$. A list of physical-chemical properties of metalloid-and halogen-doped $\mathrm{TiO}_{2}$ and their advantages are given in Table 3 .

Fluorine (F) has been doped into $\mathrm{TiO}_{2}$ to increase the percentage of the anatase phase [78]. The substitution of $\mathrm{F}$ atoms and oxygen $(\mathrm{O})$ atoms in $\mathrm{TiO}_{2}$ lattice forms $\equiv \mathrm{Ti}-$ $\mathrm{F}$ bond which has strong electron-withdrawing ability that prevents the recombination of photogenerated electron-hole pairs. However, some researchers have raised concern that beyond an optimal doping rate ( $\mathrm{F}$ concentration $>0.5 \%$ ), fluorine no longer acts as a mediator of interfacial charge transfer but serves as a recombination center [79]. The $\mathrm{pH}$ character of fluorine precursors plays an important role in determining the crystalline phase of photocatalyst formed. Basic fluorine precursors favor the formation of pure anatase phase $\mathrm{TiO}_{2}$, whereas acidic fluorine precursors favor the formation of rutile/anatase or pure rutile phase $\mathrm{TiO}_{2}$. On the other hand, fluorine was reported that it has no effect on the changes of band gap width [80]. Xu et al. [81] reported that the fluorine-doped $\mathrm{TiO}_{2}$ prepared by hydrolysis process can improve the crystallinity as well as inhibit the grain growth of photocatalyst. Instead of this, fluorine doping can enhance the formation of hydroxyl groups on the titania surface, and thus, increase the phenol photodegradation rate.

Iodine is used to enhance the surface properties as well as the optical properties of $\mathrm{TiO}_{2}$. Iodine is an effective dopant in shifting the absorption spectra of $\mathrm{TiO}_{2}$ from UV light region to visible light region and facilitating the charge separation. The presence of iodine can also narrow the band gap of $\mathrm{I}-\mathrm{TiO}_{2}$, and hence improve the absorption ability of photocatalyst in the visible light region [88]. The red-shift of the band edge of iodine-doped $\mathrm{TiO}_{2}$ is related to the formation of Helmholtz potential on the surface of $\mathrm{TiO}_{2}$ with the presence of iodine. The presence of iodine facilitates the reduction of $\mathrm{TiO}_{2}$ band gap energy from $3.2 \mathrm{eV}$ to $3.0 \mathrm{eV}$ and thus extends the photo-response region of $\mathrm{I}_{-} \mathrm{TiO}_{2}$ to the visible light region [90]. This phenomenon was due to the shirting of the electron configuration of elements where I $5 p$ states mix with $\mathrm{Ti} 3 \mathrm{~d}$ while $\mathrm{O} 2 \mathrm{p}$ moves to high energy region [91]. Wang et al. [89] successfully prepared single anatase phase of iodine-doped $\mathrm{TiO}_{2}$ using hydrothermal method and they also showed that the iodine dopants hindered the growth of crystal particles by enhancing the energy barrier mutual diffusion between grains. From their results, the existence of iodine mainly improved the photosensitivity of the photocatalyst, broadened the visible light range, and decreased the band gap energy of $\mathrm{TiO}_{2}$. Iodine dopants were proven to increase the formation of surface hydroxyl groups and thus improve the photocatalytic activity of $\mathrm{TiO}_{2}$ [90]. However, beyond an optimal doping rate, iodine dopants serve as recombination centers for the charge carriers and hence inhibit the photocatalytic activities of the doped $\mathrm{TiO}_{2}$ [88].

Boron (B) is known as a metalloid compound, which can be termed either a metal or a nonmetal. Some researchers contend that boron inhibits the growth of $\mathrm{TiO}_{2}$ crystalline and thus increases the surface area of $\mathrm{B}$-doped $\mathrm{TiO}_{2}$ as well as inducing the crystalline process [63]. The formation of anatase phase is also promoted by adding boron dopants in the formation of nano-doped-TiO 2 . For example, $\mathrm{Xu}$ et al. [66] found that $B$ increased the surface area of nanodoped- $-\mathrm{TiO}_{2}$ by controlling the growth of $\mathrm{TiO}_{2}$. Lu et al. [92] synthesized $\mathrm{B}-\mathrm{TiO}_{2}$ with the mixture of anatase and brookite phase by sol gel method. The foregoing notwithstanding, there are other researchers who are of the view that boron inhibits the transformation of amorphous phase to anatase phase. For instance, Zaleska et al. [82] found that no anatase phase was formed in the formation of boron-doped $\mathrm{TiO}_{2}$ using sol gel method. Grabowska et al. [83] found out that boron-doped $\mathrm{TiO}_{2}$ had lower surface area as compared to undoped $\mathrm{TiO}_{2}$. One of the important features in boron doping is the red shift in the absorption band of $\mathrm{TiO}_{2}$. The formation of Ti-O-B species enables the $\mathrm{B}-\mathrm{TiO}_{2}$ active in phenol photodegradation under visible light irradiation [82]. The incorporation of boron atoms into $\mathrm{TiO}_{2}$ matrix by occupying $\mathrm{O}$ sites to form $\mathrm{O}$-Ti-B induced the visible light photocatalytic activity of $\mathrm{B}-\mathrm{TiO}_{2}$ [92]. However, beyond an optimal doping rate, diboron trioxide phase $\left(\mathrm{B}_{2} \mathrm{O}_{3}\right)$ was formed in the doped $\mathrm{TiO}_{2}$, which led to lower the photocatalytic activity [82]. 
TABLE 3: Properties of metalloid or halogen-doped $\mathrm{TiO}_{2}$ photocatalysts under various conditions.

\begin{tabular}{|c|c|c|c|c|c|c|c|c|}
\hline $\begin{array}{l}\text { Type of } \\
\text { dopant }\end{array}$ & $\begin{array}{l}\text { (Metal } \\
\left.\text { dopant } / \mathrm{TiO}_{2}\right) \\
\text { molar ratio }\end{array}$ & $\begin{array}{l}\text { Preparation of } \\
\text { doped } \mathrm{TiO}_{2}\end{array}$ & $\begin{array}{l}\text { Starting } \\
\text { material of } \\
\mathrm{TiO}_{2}\end{array}$ & $\begin{array}{l}\text { Starting } \\
\text { material of } \\
\text { dopants }\end{array}$ & $\begin{array}{l}\text { Crystallite } \\
\text { size }(n m)\end{array}$ & Phase & $\begin{array}{l}\text { BET surface } \\
\text { area }\left(\mathrm{m}^{2} / \mathrm{g}\right)\end{array}$ & Reference \\
\hline \multicolumn{9}{|l|}{ Metalloid } \\
\hline \multirow{4}{*}{ B } & 0.001 & Hydrothermal & $\mathrm{Ti}(\mathrm{OBu})_{4}$ & $\mathrm{NaBH}_{4}$ & 2.59 & Anatase & 268.31 & {$[63]$} \\
\hline & 9.000 & Sol gel & $\mathrm{Ti}(\mathrm{OBu})_{4}$ & $\mathrm{VO}(\mathrm{OPr})_{3}$ & 6.00 & Anatase & 127.00 & {$[66]$} \\
\hline & 0.040 & Sol gel & TTIP & $\mathrm{H}_{3} \mathrm{BO}_{3}$ & - & Anatase & 219.00 & {$[82]$} \\
\hline & 0.148 & Sol gel & $\mathrm{TiO}_{2}$ & $\left(\mathrm{C}_{2} \mathrm{H}_{5} \mathrm{O}\right)_{3} \mathrm{~B}$ & 7.00 & Anatase & 192.00 & [83] \\
\hline \multirow{3}{*}{$\mathrm{Si}$} & 0.111 & Destabilization & HFTA & HFSA & 6.50 & - & 155.00 & {$[84]$} \\
\hline & 0.030 & Hydrothermal & $\mathrm{Ti}\left(\mathrm{OC}_{4} \mathrm{H}_{9}\right)_{4}$ & $\left(\mathrm{C}_{2} \mathrm{H}_{5}\right)_{4} \mathrm{SiO}_{4}$ & 8.20 & Anatase & 191.70 & [85] \\
\hline & 0.150 & Templating & ТВОТ & TEOS & 10.00 & Anatase & 120.00 & {$[86]$} \\
\hline \multicolumn{9}{|l|}{ Halogen } \\
\hline \multirow{6}{*}{$\mathrm{F}$} & 0.050 & Hydrothermal & $\mathrm{Ti}\left(\mathrm{OC}_{3} \mathrm{H}_{7}\right)_{4}$ & $\mathrm{NH}_{4} \mathrm{~F}$ & - & Anatase & 48.00 & {$[75]$} \\
\hline & 0.500 & Hydrothermal & ТВОТ & $\mathrm{NH}_{4} \mathrm{HF}_{2}-\mathrm{H}_{2} \mathrm{O}$ & 11.20 & Anatase & 122.00 & {$[77]$} \\
\hline & 0.770 & Hydrothermal & TIP & $\mathrm{NaF}$ & 10.00 & Anatase & 148.00 & {$[78]$} \\
\hline & 0.039 & Sol gel & $\mathrm{Ti}\left(\mathrm{C}_{2} \mathrm{H}_{5} \mathrm{O}\right)_{4}$ & $\mathrm{CF}_{3} \mathrm{COOH}$ & 13.20 & Anatase & - & {$[80]$} \\
\hline & 0.190 & Spray pyrolysis & $\mathrm{H}_{2} \mathrm{TiF}_{6}$ & $\mathrm{H}_{2} \mathrm{TiF}_{6}$ & - & Anatase & 27.10 & [87] \\
\hline & 0.001 & Sol gel & $\mathrm{Ti}(\mathrm{OBu})_{4}$ & $\mathrm{NH}_{4} \mathrm{~F}$ & 3.78 & Anatase & 169.48 & {$[81]$} \\
\hline \multirow{3}{*}{ I } & 0.033 & Hydrothermal & TTIP & $\mathrm{HIO}_{3}$ & 5.50 & Anatase/brookite & 137.60 & {$[88]$} \\
\hline & 0.117 & Hydrothermal & TNBT & KI & 4.46 & Anatase & 184.87 & [89] \\
\hline & 0.025 & Sol gel & $\mathrm{Ti}(\mathrm{OBu})_{4}$ & $\mathrm{HIO}_{3}$ & 5.50 & Anatase & 259.10 & [90] \\
\hline
\end{tabular}

Silicon is another common metalloid used to dope $\mathrm{TiO}_{2}$. Silicon dopants were proven to increase the thermal stability of anatase as well as suppress the anatase-to-rutile phase transformation [86]. Estruga et al. [84] studied the effect of silicon dopant on the formation of $\mathrm{TiO}_{2}$ nanopowders. It was reported that the incorporation of silicon did not affect the crystalline phase or $\mathrm{TiO}_{2}$ optical properties as compared to undoped $\mathrm{TiO}_{2}$. However, silicon doping did increase the surface area of doped- $\mathrm{TiO}_{2}$ with respect to undoped powders. In other study on the effects of the silicon dopants [85], $\mathrm{Si}-\mathrm{TiO}_{2}$ of smaller crystal size, larger pore volume and surface area, and single anatase phase was successfully synthesized using hydrothermal method. Meanwhile, the presence of Ti-O-Si bonds preserved high surface hydroxyl group concentrations, which influenced the subsequent photocatalytic activity of $\mathrm{TiO}_{2}$. The nature behaviors of silicon metalloid can easily produce the hybridization bands in both valence and conduction bands which are beneficial in increasing the photogenerated charge carriers. Furthermore, the silicon doping can also reduce the band gap energy of $\mathrm{TiO}_{2}$ and broaden the absorption spectra of $\mathrm{TiO}_{2}[93]$.

3.4. Effect of Codoping. In order to further improve the morphology of $\mathrm{TiO}_{2}$, the co-doping technique with double metal dopants, double nonmetal dopants, and double metalnonmetal dopants has gained wide attention. Co-doped $\mathrm{TiO}_{2}$ shifts the absorption edge of $\mathrm{TiO}_{2}$ successfully from ultraviolet region to visible light region. The co-doping technique also improves the physical properties of the $\mathrm{TiO}_{2}$ such as specific surface area and crystallite size while it sustains the phase transformation of anatase to rutile phase
[94]. Improved performance of $\mathrm{TiO}_{2}$ under visible light is achieved up to an optimal doping level, after which performance deteriorates when the dopants become recombination centers for photogenerated electron-hole pairs [95].

A variety of rare metal dopants, including niobium $(\mathrm{Nb})$, tungsten (W) and samarium (Sm) have been used in the codoping technique by several researchers [96-98]. As with the other classes of dopants, $\mathrm{Nb}$ prevents the recombination of free electron and energized hole and extends the wavelength of absorbance of $\mathrm{TiO}_{2}$ to increase its functionality. [97]. Ti atoms have been replaced with $\mathrm{W}$ atoms to form $\mathrm{W}-\mathrm{O}-\mathrm{Ti}$ bonds, which can induce the formation of the anatase phase as well as act as electron traps to suppress the recombination of energized holes and free electrons. Similar to other dopants, an excess of $\mathrm{W}$ levels decreases the performance of $\mathrm{TiO}_{2}$. W is deposited on the surface of $\mathrm{TiO}_{2}$ to blue-shift the absorption edge, thus increasing the band gap energy of $\mathrm{TiO}_{2}$ under visible light [98]. Sm is also used to dope into $\mathrm{TiO}_{2}$, which again restrains the phase transformation of the anatase phase to solid form and also stabilizes it in the final product. It also prevents the growth of the crystallite size of $\mathrm{TiO}_{2}$ [96].

In the co-doping technique, the functions of metal dopants are generally to facilitate the charge separation of free electrons and energized holes and to decrease their recombination [97-99]. On the other hand, the functions of nonmetal dopants are generally to shift the absorption region of $\mathrm{TiO}_{2}$ from the UV light region to the visible light region, besides narrowing the band gap of $\mathrm{TiO}_{2}[100-102]$. For example, $\mathrm{Cu}$ is applied in the co-doping technique to slow the growth of crystallite size of the $\mathrm{TiO}_{2}$ by forming a complex with oxygen on the surface of $\mathrm{TiO}_{2}$. At the same 
TABLE 4: Properties of codoped- $\mathrm{TiO}_{2}$ catalysts under various conditions.

\begin{tabular}{|c|c|c|c|c|c|c|c|c|}
\hline $\begin{array}{l}\text { Type of } \\
\text { dopants } \\
\text { used }(x, y)\end{array}$ & $\begin{array}{l}\text { Optimum } \\
\text { molar } \\
\text { ratio of the } \\
\text { dopants } \\
\left(\mathrm{M}_{x}: \mathrm{M}_{y}\right) \\
\end{array}$ & $\begin{array}{l}\text { Codoped } \mathrm{TiO}_{2} \\
\text { preparation } \\
\text { method }\end{array}$ & $\begin{array}{l}\text { Starting material of } \\
\mathrm{TiO}_{2}\end{array}$ & $\begin{array}{l}\text { Starting material of } \\
\text { co-dopants }\end{array}$ & $\begin{array}{l}\text { Particle } \\
\text { size }(\mathrm{nm})\end{array}$ & Phase & $\begin{array}{l}\text { BET surface } \\
\text { area }\left(\mathrm{m}^{2} / \mathrm{g}\right)\end{array}$ & Reference \\
\hline $\mathrm{F}, \mathrm{N}$ & 1.00 & Sol gel & TTIP & $\mathrm{NH}_{4} \mathrm{~F}, \mathrm{NH}_{4} \mathrm{Cl}$ & - & Anatase & 102.00 & {$[74]$} \\
\hline $\mathrm{Sm}, \mathrm{N}$ & 1.50 & Coprecipitation & $\mathrm{Ti}\left(\mathrm{SO}_{4}\right)_{2}$ & $\mathrm{Sm}\left(\mathrm{NO}_{3}\right)_{3}, \mathrm{NH}_{3}$ & 8.80 & Anatase/Rutile & 170.00 & {$[96]$} \\
\hline $\mathrm{Fe}, \mathrm{Nb}$ & 0.12 & Sol gel & TTIP & $\begin{array}{l}\mathrm{Fe}\left(\mathrm{NO}_{3}\right)_{3} \bullet 9 \mathrm{H}_{2} \mathrm{O}, \\
\mathrm{C}_{4} \mathrm{NH}_{4} \mathrm{NbO}_{9} \bullet 10 \mathrm{H}_{2} \mathrm{O}\end{array}$ & 10.00 & Anatase & 120.20 & {$[97]$} \\
\hline $\mathrm{W}, \mathrm{N}$ & 1.60 & Hydrolysis & $\mathrm{TiCl}_{4}$ & $\left(\mathrm{NH}_{4}\right)_{2} \mathrm{WO}_{4}$ & 11.00 & Anatase & 80.00 & {$[98]$} \\
\hline $\mathrm{B}, \mathrm{Fe}$ & 3.00 & Sol gel & $\mathrm{Ti}(\mathrm{OBu})_{4}$ & $\mathrm{H}_{3} \mathrm{BO}_{3}, \mathrm{Fe}(\mathrm{acac})_{3}$ & 12.00 & Anatase & 60.00 & [99] \\
\hline $\mathrm{N}, \mathrm{S}$ & 1.00 & Hydrolysis & $\mathrm{Ti}\left(\mathrm{SO}_{4}\right)_{2}$ & $\mathrm{NH}_{3} \bullet \mathrm{H}_{2} \mathrm{O}, \mathrm{Ti}\left(\mathrm{SO}_{4}\right)_{2}$ & 38.20 & Anatase & 56.10 & {$[100]$} \\
\hline$S, I$ & 1.00 & Sol gel & TIP & Thiourea, $\mathrm{HIO}_{3}$ & 8.80 & Anatase & 85.00 & {$[101]$} \\
\hline $\mathrm{N}, \mathrm{S}$ & 33.33 & Hydrothermal & $\mathrm{Ti}\left(\mathrm{SO}_{4}\right)_{2}$ & $\mathrm{CH}_{4} \mathrm{~N}_{2} \mathrm{~S}, \mathrm{Ti}\left(\mathrm{SO}_{4}\right)_{2}$ & 16.20 & Anatase & - & {$[102]$} \\
\hline $\mathrm{Cu}, \mathrm{S}$ & 2.00 & Sol gel & TIP & $\mathrm{CuCl}_{2} \cdot 2 \mathrm{H}_{2} \mathrm{O}$, Thiourea & 8.00 & Anatase & - & {$[103]$} \\
\hline $\mathrm{F}, \mathrm{N}$ & 1.00 & Sol gel & $\mathrm{TiCl}_{4}$ & $\mathrm{NH}_{4} \mathrm{~F}$ & 11.90 & Anatase & 160.70 & {$[104]$} \\
\hline $\mathrm{Pt}, \mathrm{Cu}$ & 12.50 & Impregnation & $\begin{array}{l}\text { Titanium } \\
\text { Tetraisobutyloxide }\end{array}$ & $\mathrm{H}_{2} \mathrm{PtCl}_{6}, \mathrm{Cu}\left(\mathrm{NO}_{3}\right)_{2}$ & 8.90 & Anatase & 105.90 & {$[105]$} \\
\hline $\mathrm{Fe}, \mathrm{C}$ & 0.57 & $\begin{array}{l}\text { Sol } \\
\text { gel/Solvothermal }\end{array}$ & Tetrabutyl titanate & $\mathrm{Fe}\left(\mathrm{NO}_{3}\right)_{3} \bullet 9 \mathrm{H}_{2} \mathrm{O}$ & 10.80 & Anatase & 158.00 & {$[106]$} \\
\hline Pt, N & 0.02 & Sol gel & TTIP & $\mathrm{H}_{2} \mathrm{PtCl}_{6}, \mathrm{NH}_{2} \mathrm{CONH}_{2}$ & 5.00 & Anatase & 72.50 & {$[107]$} \\
\hline $\mathrm{Cr}, \mathrm{W}$ & 2.00 & Pyrolysis & $\mathrm{Ti}_{2}\left(\mathrm{C}_{2} \mathrm{O}_{4}\right)_{3} \cdot 10 \mathrm{H}_{2} \mathrm{O}$ & $\begin{array}{l}\left(\mathrm{NH}_{4}\right)_{2} \mathrm{Cr}_{2} \mathrm{O}_{7} \\
\text { Dimethylammonium } \\
\text { tungstate }\end{array}$ & 30.00 & Anatase & 60.00 & {$[108]$} \\
\hline
\end{tabular}

time, $\mathrm{Cu}$ also prohibits the phase transformation from the anatase phase to the rutile phase [103]. carbon (C) and iodine (I) are similarly used as dopants to improve the performance and properties of $\mathrm{TiO}_{2}$ [101].

The co-doping technique generates synergistic effects which enhance the properties of the final $\mathrm{TiO}_{2}$ product [74, 96-109]. For example, when $\mathrm{W}$ and $\mathrm{N}$ are co-doped to $\mathrm{TiO}_{2}$, the excited electrons are easily transferred from valence band into the new conduction band due to the narrowing of the band gap difference, while the recombination of free electrons and holes are not permitted [98]. Livraghi et al. [74] researched the effects of the co-doping technique using $\mathrm{F}$ and $\mathrm{N}$ on the formation of $\mathrm{TiO}_{2}$. F could activate the active site of $\mathrm{N}$ by producing extra electrons to the low energy orbital of $\mathrm{N}_{\mathrm{b}}{ }^{\bullet}$. Doping with $\mathrm{F}$ and $\mathrm{N}$ created a synergism in which $\mathrm{F}$ improved the incorporation of $\mathrm{N}$ dopant into $\mathrm{TiO}_{2}$.

Hamadanian et al. [103] showed that the use of $\mathrm{Cu}$ and $\mathrm{S}$ could form co-doped $\mathrm{TiO}_{2}$ with $\mathrm{TiO}_{2}$ displaying high performance under visible light irradiation. In this instance, $\mathrm{Cu}$ shifted the absorption range of $\mathrm{TiO}_{2}$ from the $\mathrm{UV}$ region to the visible light region, while $\mathrm{S}$ lowered the band gap energy of $\mathrm{TiO}_{2}$ by mixing its electron orbital with the $\mathrm{O} 2 \mathrm{p}$ orbital.

Overall, the co-doping technique is an effective method to improve the performance of $\mathrm{TiO}_{2}$. A list of physicalchemical properties of co-doped $\mathrm{TiO}_{2}$ and its advantages is given in Table 4. Three main benefits of co-doping are (1) high percentage of the anatase phase can be obtained, (2) phase transformation of the anatase phase to the rutile phase is inhibited, and (3) small crystallite size and high specific surface area of $\mathrm{TiO}_{2}$ are obtained [74, 96-109].

\section{Effect of the Presence of Dopants on the Photocatalytic Degradation of Organic Pollutants}

Various attempts at metal doping, nonmetal doping, and co-doping have been made to limit the recombination of the photogenerated electron-hole pairs in photocatalysis. Generally, doped $\mathrm{TiO}_{2}$ performs better in the degradation of organic pollutants as compared with pure $\mathrm{TiO}_{2}$ due to the modifications of the physical and chemical properties of $\mathrm{TiO}_{2}$. In terms of physical properties, the doped $\mathrm{TiO}_{2}$ has smaller crystallite size, larger specific surface area, and higher proportion of the anatase phase. The smaller crystallite size of doped $\mathrm{TiO}_{2}$ reduces the likelihood of energized holes and free electron recombining, while the photocatalytic activity of $\mathrm{TiO}_{2}$ is furthered enhanced by the charge carrier space distance being increased. Ma et al. [96] stated that dopants played an important role in the photocatalysis to create a charge space carrier region on the surface of $\mathrm{TiO}_{2}$ that prevents the recombination of electronhole pairs. The photodegradation process takes place on the surface of the photocatalyst, and a larger specific surface area makes available more active sites on the catalyst surface that increases the photodegradation potential of the photocatalyst $[49,66,69,70,98,106]$. 
TABle 5: Comparison on the photocatalytic degradation rate of different organic pollutants between pure $\mathrm{TiO}_{2}$ and doped $\mathrm{TiO}_{2}$.

\begin{tabular}{|c|c|c|c|c|c|c|c|}
\hline \multirow{2}{*}{ Dopant(s) } & \multirow{2}{*}{ Light source } & \multirow{2}{*}{ Organic pollutant } & \multirow{2}{*}{$\begin{array}{l}\text { Initial pollutant } \\
\text { concentration }(\mathrm{mg} / \mathrm{L})\end{array}$} & \multirow{2}{*}{$\begin{array}{l}\text { Irradiation time } \\
(\mathrm{h})\end{array}$} & \multicolumn{2}{|c|}{ Degradation efficiency (\%) } & \multirow{2}{*}{ Reference } \\
\hline & & & & & Doped $\mathrm{TiO}_{2}$ & Pure $\mathrm{TiO}_{2}$ & \\
\hline \multirow{4}{*}{$\mathrm{Fe}$} & Visible light & Malachite green & 5.00 & 1.00 & 78 & 63 & {$[49]$} \\
\hline & Visible light & Yellow XRG dye & 100.00 & 8.00 & 37 & 18 & {$[50]$} \\
\hline & Visible light & Methyl orange & 20.00 & 6.00 & 70 & 50 & {$[53]$} \\
\hline & UV light & Dichloromethane & $96.00 \pm 3.00$ & 2.00 & 88 & 82 & {$[54]$} \\
\hline \multirow{2}{*}{$\mathrm{Pt}$} & UV light & Methyl orange & 20.00 & 1.50 & 98 & 90 & {$[58]$} \\
\hline & & Acid green 16 & 1.20 & 1.00 & 100 & 98 & {$[57]$} \\
\hline $\mathrm{Ce}$ & UV light & Rhodamine B & 0.50 & 2.00 & 80 & 98 & {$[62]$} \\
\hline \multirow{2}{*}{ B } & Visible light & 4-chlorophenol & 50.00 & 4.00 & 78 & 20 & {$[63]$} \\
\hline & UV light & Methylene blue & 19.00 & 4.00 & 98 & 78 & {$[66]$} \\
\hline $\mathrm{Cu}$ & Visible light & Methylene orange & 10.00 & 0.75 & 100 & 70 & {$[103]$} \\
\hline $\mathrm{F}$ & UV light & Methylene blue & 8.00 & 1.00 & 92 & 30 & {$[79]$} \\
\hline $\mathrm{N}$ & Visible light & Methylene orange & 20.00 & 1.00 & 14 & 1 & {$[76]$} \\
\hline \multirow{2}{*}{ S } & Visible light & 4 chlorophenol & 0.32 & 6.00 & 88 & 5 & {$[70]$} \\
\hline & UV light & Methylene orange & 20.00 & 1.67 & 98 & 70 & {$[69]$} \\
\hline S, I & Visible light & Methylene blue & 8.00 & 4.00 & 90 & 20 & {$[101]$} \\
\hline $\mathrm{W}, \mathrm{N}$ & UV light & Phenol & 60.00 & 4.00 & 93 & 83 & {$[98]$} \\
\hline $\mathrm{Sm}, \mathrm{N}$ & Visible light & Salicylic acid & 50.00 & 5.00 & 65 & 3 & {$[96]$} \\
\hline $\mathrm{Fe}, \mathrm{C}$ & Visible light & Acid orange 7 & 50.00 & 5.00 & 90 & 8 & {$[106]$} \\
\hline
\end{tabular}

Dopants narrow the band gap of the photocatalysts and enhance their photocatalytic abilities by shifting their photocatalytic activity from the ultra violet region to the visible light region. For example, Hamadanian et al. [103] reported that $\mathrm{Cu}$ and $\mathrm{S}$ could alter the optical absorption wavelength of $\mathrm{TiO}_{2}$ from UV light to visible light and hence lower the band gap of $\mathrm{TiO}_{2}$ through the combination of electron orbital between $\mathrm{S}$ and $\mathrm{O}$, respectively.

The photocatalytic activity of $\mathrm{TiO}_{2}$ can be improved when chemical properties of doped $\mathrm{TiO}_{2}$ are altered. Free electron and energized holes are the most important species in photocatalysis as hydroxyl radical can be produced from the energized holes during the reaction between water and the energized holes [79, 103]. The addition of dopants elevates $\mathrm{TiO}_{2}$ efficiency by reducing the recombination of energized holes and free electrons. This accelerates the formation of hydroxyl radicals to speed up the photodegradation process $[57,106]$. When $\mathrm{Fe}$ is used as a dopant, for example, the stable form of $\mathrm{Fe}^{3+}$ can be oxidized or reduced to form $\mathrm{Fe}^{2+}$ and $\mathrm{Fe}^{4+}$. Hence, $\mathrm{Fe}$ with its d orbital can act as intermediate for both energized holes and free electrons transfer. This speeds up the degradation of organic pollutants by preventing the recombination of energized holes and free electrons. Fe also lowers the conduction band energy and increases the valence band energy of $\mathrm{TiO}_{2}$. The end result is the enhancement of photodegradation efficiency under visible light $[49,50,53,54]$.

In short, dopants can act as active sites for pollutant adsorption to facilitate the photodegradation reaction [96]. However, excessive amounts of dopants can retard the photocatalysis process. They reduce the opportunity of oxygen photoadsorbed on the surface of $\mathrm{TiO}_{2}$ to react with free electrons to form $\mathrm{O}_{2}{ }^{-}$or the corresponding hole to form $\cdot \mathrm{OH}$. Excess amounts of dopants deposited on surface of $\mathrm{TiO}_{2}$ also increase the recombination rate of free electrons and energized holes, thus inhibiting the photodegradation process [57].

A summary of various dopants of $\mathrm{TiO}_{2}$ applied in photocatalysis for the removal of organic pollutants is given in Table 5, which also compares the degradation efficiency between doped $\mathrm{TiO}_{2}$ and pure $\mathrm{TiO}_{2}$. Overall, dopants improve the performance of pure $\mathrm{TiO}_{2}$ in the degradation of organic pollutants under visible light irradiation. They narrow the band gap of $\mathrm{TiO}_{2}$ by shifting the optical absorption wavelength of $\mathrm{TiO}_{2}$ from UV light to visible light.

\section{Operational Factors Affecting the Photocatalytic Degradation}

Based on the critical analysis of the existing researchers on the photocatalytic degradation of the organic pollutants, the important operating parameters affecting the efficiency of the photocatalytic degradation process are selected and discussed as follows: calcination temperature of nanodoped- $\mathrm{TiO}_{2}$, initial concentration of photocatalyst, initial concentration of the reactant, and initial concentration of dopant dosing.

5.1. Effect of Calcination Temperature of Nano-Doped-TiO 2 . Calcination process is commonly applied in the formation of $\mathrm{TiO}_{2}$ photocatalyst as it can enhance the photocatalytic activity of photocatalyst. Deng et al. [46] studied the effect of calcination temperature on the photocatalytic performance of $\mathrm{Fe}-\mathrm{TiO}_{2}$. As shown in their results, the calcined $\mathrm{Fe}-\mathrm{TiO}_{2}$ 
TABLE 6: Effect of calcination temperature of nano-doped- $\mathrm{TiO}_{2}$ on the photocatalytic degradation process.

\begin{tabular}{|c|c|c|c|c|c|c|c|c|c|}
\hline $\begin{array}{l}\text { Type of } \\
\text { dopant }\end{array}$ & $\begin{array}{l}\text { Doped } \mathrm{TiO}_{2} \\
\text { preparation } \\
\text { method }\end{array}$ & $\begin{array}{l}\text { Doped } \\
\mathrm{TiO}_{2} \\
\text { loading } \\
(\mathrm{g} / \mathrm{L})\end{array}$ & $\begin{array}{l}\text { Range of } \\
\text { calcination } \\
\text { temperature } \\
\left({ }^{\circ} \mathrm{C}\right)\end{array}$ & $\begin{array}{l}\text { Optimum } \\
\text { calcination } \\
\text { temperature } \\
\left({ }^{\circ} \mathrm{C}\right)\end{array}$ & $\begin{array}{l}\text { Organic } \\
\text { pollutant }\end{array}$ & $\begin{array}{l}\text { Initial } \\
\text { pollutant } \\
\text { concentra- } \\
\text { tion } \\
(\mathrm{mg} / \mathrm{L})\end{array}$ & Light source & $\begin{array}{l}\text { Degradation } \\
\text { efficiency, \% }\end{array}$ & Reference \\
\hline $\mathrm{Fe}$ & Sol gel & 5.0 & $200-400$ & 400 & Methyl orange & 20 & UV-vis & 99.7 & {$[46]$} \\
\hline $\mathrm{Pt}$ & $\begin{array}{l}\text { Photochemical } \\
\text { reduction }\end{array}$ & 2.0 & $110-500$ & 110 & Methyl orange & 20 & UV & 87.8 & {$[58]$} \\
\hline I, F & $\begin{array}{l}\text { Sol gel- } \\
\text { impregnation }\end{array}$ & 1.0 & $500-700$ & 500 & $\begin{array}{l}\text { Methylene } \\
\text { blue }\end{array}$ & 10 & Sunlight & 98 & {$[94]$} \\
\hline $\mathrm{Sm}, \mathrm{N}$ & Coprecipitation & 1.0 & $300-600$ & 400 & Salicylic acid & 50 & Visible light & 67 & {$[102]$} \\
\hline $\mathrm{Fe}$ & Sol gel & 1.0 & 0-900 & 500 & Reactive blue 4 & 70 & Ultrasonic & 82 & {$[110]$} \\
\hline $\mathrm{N}, \mathrm{S}$ & Hydrolysis & 0.02 & $400-800$ & 500 & Formaldehyde & 350 & Sunlight & 65 & {$[100]$} \\
\hline $\mathrm{Cu}, \mathrm{S}$ & Sol gel & 1.0 & $500-850$ & 500 & Methyl orange & 10 & Visible & 100 & {$[103]$} \\
\hline $\mathrm{Pt}, \mathrm{Cu}$ & Impregnation & 1.0 & $300-700$ & 300 & Nitrate & 10 & UV & 90 & {$[105]$} \\
\hline $\operatorname{Pr}$ & Sol gel & 1.0 & $100-800$ & 600 & Phenol & 50 & UV & 96 & {$[111]$} \\
\hline KOX & Sol gel & 1.0 & $.0-1000$ & 800 & $\begin{array}{l}\text { Methylene } \\
\text { blue }\end{array}$ & 20 & $\begin{array}{l}\text { Fluorescence } \\
\text { blacklight }\end{array}$ & 100 & {$[112]$} \\
\hline
\end{tabular}

showed higher photocatalytic activity compared to that Fe$\mathrm{TiO}_{2}$ formed in the absence of calcination process. It was attributed to the formation of anatase phase from titanate.

However, beyond the optimum calcination temperature, the photocatalytic activity of photocatalyst is observed to decrease due to the agglomeration and sintering damage of $\mathrm{Fe}-\mathrm{TiO}_{2}$ at high temperature [94]. Huang et al. [58] studied the effect of calcination temperature on the photocatalytic activity of Pt-doped $\mathrm{TiO}_{2}$. Based on their results, the calcined $\mathrm{Pt}-\mathrm{TiO}_{2}$ was confirmed to have higher efficiency and activity in the photocatalytic degradation of pollutant up to certain optimum calcination temperature. Beyond the optimum calcination temperature, the photocatalytic activity was observed to decrease due to the agglomeration of particles which reduce the specific surface area of the photocatalyst.

Calcination process can influence the surface area, morphology, and crystallinity of the prepared photocatalyst. Ma et al. [96] synthesized and calcined the co-doped $\mathrm{Sm} / \mathrm{N}-\mathrm{TiO}_{2}$ at different temperatures. The prepared photocatalysts were tested on the photodegradation of salicylic acid under visible light irradiation. They found out that calcination process improved the crystallinity, particle size, and surface area of photocatalyst as compared to undoped photocatalysts.

The calcination temperature affects greatly the optical absorption of the photocatalysts. High calcination temperature can promote the replacement of nitrogen by oxygen in the air. Consequently, the absorption of photocatalyst in the visible light region decreases, and hence, decreasing the photocatalytic activity of $\mathrm{TiO}_{2}$. Many researchers have confirmed that the calcination process is important in the formation of doped $\mathrm{TiO}_{2}$ and that the properties of photocatalyst such as surface area and crystallinity of doped $\mathrm{TiO}_{2}$ are strongly dependent on the calcination temperature $[100,103,110]$. With further increase in the calcination temperature, the surface area of $\mathrm{TiO}_{2}$ started to decrease as well as the transformation of anatase to rutile phase, and thus, the photocatalytic activity of $\mathrm{TiO}_{2}$ decreased. Li et al. [105] studied the effect of calcination temperature on benzene photodegradation using $\mathrm{Pt} / \mathrm{Cu}-\mathrm{TiO}_{2}$. They also agreed that high calcination temperature produced low specific surface area, large particle size, and low crystallinity phase of the agglomerated doped- $\mathrm{TiO}_{2}$. Subsequently, the less active site eventually lowers the photocatalytic activity of $\mathrm{TiO}_{2}$.

Suwanchawalit and Wongnawa [112] studied the photodegradation of methylene blue using potassium oxalatedoped $\mathrm{TiO}_{2}$. Based on their result, noncalcined samples have high specific surface area but low percentage of anatase phase in the $\mathrm{TiO}_{2}$. These resulted that non-calcined samples showed higher adsorptive capacity but lower photocatalytic activity as compared to calcined samples. As the calcination temperature increases, the adsorptive property of photocatalyst decreases with increasing the photocatalytic activity. In addition, the optimum calcination temperature provides the moderate adsorptive capacity and excellent photocatalytic activity of the photocatalysts. On the other hand, further increase of calcination temperature decreases the photocatalytic performance of photocatalyst. Kemp and McIntyre [113] studied the photodegradation of poly(vinyl chloride) using $\mathrm{V}-\mathrm{TiO}_{2}$ and reported that lower calcination temperature samples showed better photodegradation rate compared to that sample produced at high calcination temperature $\left(1000^{\circ} \mathrm{C}\right)$.

Table 6 summarizes the effect of calcination temperatures of nano-doped- $\mathrm{TiO}_{2}$ on the photocatalytic degradation of various organic pollutants. The table reveals that different optimum calcination temperatures have been reported by different researchers. Such differences in the preparation and posttreatment conditions contribute different morphology of nano-doped- $\mathrm{TiO}_{2}$. 
TABLE 7: Effect of initial organic pollutant concentration on the photocatalytic activity of nano-doped- $\mathrm{TiO}_{2}$.

\begin{tabular}{|c|c|c|c|c|c|c|c|c|c|}
\hline $\begin{array}{l}\text { Type of } \\
\text { dopant }\end{array}$ & $\begin{array}{l}\text { Doped } \mathrm{TiO}_{2} \\
\text { preparation } \\
\text { method }\end{array}$ & $\begin{array}{l}\text { Doped } \\
\mathrm{TiO}_{2} \\
\text { loading } \\
(\mathrm{g} / \mathrm{L})\end{array}$ & $\begin{array}{l}\text { Organic } \\
\text { pollutant }\end{array}$ & $\begin{array}{l}\text { Range of } \\
\text { pollutant } \\
\text { concentration } \\
(\mathrm{mg} / \mathrm{L})\end{array}$ & $\begin{array}{l}\text { Optimum } \\
\text { pollutant } \\
\text { concentration } \\
(\mathrm{mg} / \mathrm{L})\end{array}$ & $\begin{array}{l}\text { Light } \\
\text { source }\end{array}$ & $\begin{array}{l}\text { Irradiation } \\
\text { time (h) }\end{array}$ & $\begin{array}{l}\text { Degradation } \\
\text { efficiency } \\
(\%)\end{array}$ & Reference \\
\hline $\mathrm{Ag}$ & Sol gel & 1 & Crystal violet & $10-80$ & 10 & UV & 1.75 & 100 & {$[115]$} \\
\hline $\mathrm{Ba}$ & Sol gel & 0.2 & 4-chlorophenol & $50-300$ & 250 & UV & - & 100 & {$[10]$} \\
\hline C & Sol gel & 1 & Methylene blue & $5-50$ & 5 & Solar light & $2 / 3$ & 100 & {$[116]$} \\
\hline $\mathrm{Ce}$ & Coprecipitation & 4 & Phenol & $1000-5000$ & 1000 & UV & 2 & 100 & {$[117]$} \\
\hline $\mathrm{Fe}$ & Sol gel & 1.5 & Reactive blue 4 & $70-120$ & 70 & Ultrasonic & 1 & 92 & {$[110]$} \\
\hline $\mathrm{N}$ & Sol gel & 0.4 & Phenol & $10-200$ & 20 & UV & - & - & {$[118]$} \\
\hline $\mathrm{P}$ & Sol gel & 0.2 & Rhodamine B & $5-50$ & 12 & Solar light & - & 85 & [119] \\
\hline $\operatorname{Pr}$ & Sol gel & 1 & Phenol & $12.5-200$ & 25 & UV & 1 & 100 & [111] \\
\hline W & $\begin{array}{l}\text { Liquid phase } \\
\text { deposition }\end{array}$ & - & $\begin{array}{l}\text { Dodecyl- } \\
\text { benzenesulfonate }\end{array}$ & $250-100$ & 250 & Visible & 1.5 & 98 & {$[120]$} \\
\hline $\mathrm{Zr}$ & Sol gel & 0.2 & 4-chlorophenol & 50-300 & 250 & UV & - & 100 & [121] \\
\hline
\end{tabular}

5.2. Effect of Initial Reactant Concentration. The influence of initial reactant concentration on the photocatalytic degradation is a great aspect of the study. The relationship between initial reactant concentration and photocatalytic activity of $\mathrm{TiO}_{2}$ is associated with the adsorption of reactant on the surface of photocatalyst and the screening effect due to overloading of reactant [110]. In general, it is found that the photocatalytic activity of the photocatalysts decreases with increasing the initial reactant concentration. This may be due to the limitation of the numbers of active sites of photocatalyst available on the photocatalyst surface. On the other hand, Andronic et al. [114] reported that the photodegradation efficiency decreased when initial reactant concentration increased. This is due to the decrease of the path length of the photon when entering the reactant solution, with direct consequence on the formation of electron-hole pairs.

In other study on the effect of initial reactant concentration [117], the adsorption of phenol intermediates could lead to the irreversible deposition on the surface of $\mathrm{Ce}-\mathrm{TiO}_{2}$ photocatalyst and thus reduce the photodegradation efficiency. Meanwhile, the excessive of reactant concentration could lead to the screening effect that prohibited the penetration of light irradiation [121]. Beyond the optimum concentration of reactant, more reactant molecules will adsorb on the photocatalyst surface, prohibiting the absorption of photon to form charge carriers. Otherwise, it will also prevent the excessive adsorption of reactant on the active sites of the photocatalyst, inhibit the generation of hydroxyl radical and hence decrease the photocatalytic activity of the photocatalyst [110].

Table 7 summarizes the effect of initial reactant concentration on the photocatalytic degradation of various organic pollutants.

5.3. Effect of Photocatalyst Dosage. The effect of photocatalyst dosage on the photocatalytic degradation process has been widely studied. The reason generally advanced for this is that the optimum photocatalyst dosage maximizes the photocatalytic performance and minimizes the cost and energy.

In most of the studies, the increase in the photocatalyst dosage increases the number of photons absorbed on the photocatalyst surface, which in turn increases the generation of electron/hole pairs and increases the number of hydroxyl radicals. The increase in the photocatalyst dosage also increases the number of organic pollutant adsorbed on the surface of photocatalyst and facilitates the photocatalytic activity $[111,122]$.

However, when the photocatalyst dosage increases above the optimum level, the photocatalytic activity decreases, which is due to the shadowing effect and the penetration depth of light irradiation by the high turbidity suspension [116]. Huang et al. [58] added that as the excess catalyst prevent the penetration of light in the photocatalytic degradation process, the light scattering and the screening effect decreased among the photocatalyst particles and the efficiency of the photocatalytic degradation reduced accordingly. Furthermore, the increase of the photocatalyst dosage beyond the optimum level may result in the deactivation of the catalyst particle and the collision between the active molecules and ground state molecules of titania [10] and hence degradation rate decrease.

Wang et al. [123] studied the effect of photocatalyst amount on the photocatalytic activity of the catalyst. Based on the result obtained, the photocatalytic degradation was significantly affected by the photocatalyst dosage and that the optimal photocatalyst dosage was $1000 \mathrm{mg} / \mathrm{L}$. When in excess, existence of dopant on the particle surface of $\mathrm{TiO}_{2}$ lessens the active sites on the surface of $\mathrm{TiO}_{2}$, aids the agglomeration $\mathrm{TiO}_{2}$, and thus hinders the photocatalytic activity.

There are several considerations affecting the optimum photocatalyst dosage on the photocatalytic degradation process. These include the type of dopants, light intensity, and initial reactant concentration. Thus, further study is still required to provide a complete understanding of the 
TABLE 8: Effect of photocatalyst dosage on the photocatalytic activity of nano-doped- $\mathrm{TiO}_{2}$ in the photocatalytic degradation of various organic pollutants.

\begin{tabular}{|c|c|c|c|c|c|c|c|c|c|}
\hline $\begin{array}{l}\text { Type of } \\
\text { dopant }\end{array}$ & $\begin{array}{l}\text { Doped } \mathrm{TiO}_{2} \\
\text { preparation } \\
\text { method }\end{array}$ & $\begin{array}{l}\text { Range of } \\
\text { photo- } \\
\text { catalyst } \\
\text { dosage } \\
(\mathrm{g} / \mathrm{L})\end{array}$ & $\begin{array}{l}\text { Optimum } \\
\text { photocatalyst } \\
\text { loading }(\mathrm{g} / \mathrm{L})\end{array}$ & $\begin{array}{l}\text { Organic } \\
\text { pollutant }\end{array}$ & $\begin{array}{l}\text { Initial pollutant } \\
\text { concentration } \\
(\mathrm{mg} / \mathrm{L})\end{array}$ & Light source & $\begin{array}{l}\text { Irradiation } \\
\text { time }(\mathrm{h})\end{array}$ & $\begin{array}{l}\text { Degradation } \\
\text { efficiency } \\
(\%)\end{array}$ & Reference \\
\hline Sn & $\begin{array}{l}\text { Sol gel/dip } \\
\text { coating }\end{array}$ & $5-15$ & 12.5 & Orange-G & 50 & UV & 1 & 99.1 & {$[122]$} \\
\hline $\mathrm{Zr}$ & Sol gel & $100-500$ & 2.0 & 4-chlorophenol & 250 & UV & - & - & {$[121]$} \\
\hline $\mathrm{Ba}$ & Sol gel & $100-500$ & 2.0 & 4-chlorophenol & 250 & UV & - & - & {$[10]$} \\
\hline \multirow{2}{*}{$\mathrm{Fe}$} & Hydrothermal & $0.25-1.25$ & 1.0 & Azo fuchsine & 10 & Ultrasonic & 1 & 60 & {$[123]$} \\
\hline & Sol gel & $0.5-2.0$ & 1.5 & Reactive Blue 4 & 70 & Ultrasonic & 1 & 90 & {$[110]$} \\
\hline $\mathrm{Ag}$ & $\begin{array}{l}\text { Photo } \\
\text { reduction }\end{array}$ & $326-2608$ & 3.0 & Direct Red 23 & 326 & UV & 2.5 & 55 & {$[124]$} \\
\hline $\mathrm{C}$ & Sol gel & $0.5-4.0$ & 1.0 & Methylene blue & 10 & Solar lgiht & 1.67 & 100 & {$[116]$} \\
\hline $\mathrm{P}$ & Sol gel & $0.2-1.2$ & 0.4 & Rhodamine B & 12 & Sunlight & 4 & 93 & [119] \\
\hline \multirow{2}{*}{$\operatorname{Pr}$} & Sol gel & $0.0-1.2$ & 1.0 & Phenol & 50 & UV & 2 & 96.5 & {$[111]$} \\
\hline & Sol gel & $0.5-6.0$ & 3.0 & Methyl orange & 20 & UV & 0.5 & 90.5 & {$[58]$} \\
\hline
\end{tabular}

relationship between photocatalyst dosage and other parameters. Table 8 shows the effect of photocatalyst dosage on the photocatalytic degradation of various organic pollutants.

5.4. Effect of Dopant Concentration. Dopant concentration on the photocatalytic activity of photocatalysts has been investigated. The photocatalytic activity was found to be directly proportional to the dopant concentration. However, it was noticed that above a certain level of concentration, the photocatalytic performance decreases.

In Deng et al.'s research [46], the increasing rate of the photocatalytic degradation slowed down when the dopant concentration of Fe was higher than $0.5 \%$. This indicated that $\mathrm{Fe}^{3+}$ ions acted as photogenerated electron trap, so the recombination of hole-electron pairs was inhibited. Meanwhile, the transfer of electron from $\mathrm{Fe}^{2+}$ to $\mathrm{Ti}^{4+}$ surface due to the proximity of the energy levels was also one of the factors in enhancing photocatalytic activity. This is in agreement with recent reports [50, 53, 55]. Zhu et al. [50] also reported an enhancement degradation rates for $\mathrm{Fe}$-doped $\mathrm{TiO}_{2}$ prepared by hydrothermal treatment as compared to undoped $\mathrm{TiO}_{2}$ in the photodegradation of active yellow XRG. Tong et al. [53] and Ambrus et al. [55] reported an improved photocatalytic performance for the optimum Fe dopant concentration. Beyond the optimum concentration of dopant, the photodegradation rate decreased.

On the other hand, noble metals such as $\mathrm{Pt}, \mathrm{Au}$, and $\mathrm{Pd}$ are always advantageous to the photocatalytic degradation process. Sakthivel et al. [57] studied the effect of dopant concentration on the photocatalytic degradation of acid green 16 using doped $\mathrm{TiO}_{2}$. In their research, the optimum dopant loading concentration enhanced the photocatalytic activity by increasing the photonic efficiency and inhibiting the electron-hole pair recombination. However, any further increase in dopant content exert is negative effect on the photocatalytic activity of the photocatalyst. When in excess, the existence of dopant on the $\mathrm{TiO}_{2}$ surface blocks the active sites of $\mathrm{TiO}_{2}$, lessens the adsorption of reactant, and, thereby, reduces the photodegradation efficiency. Huang et al. [58] also studied the decolorization performance of methyl orange using Pt-doped $\mathrm{TiO}_{2}$. They observed that there was a great enhancement in the decolorization by doping $\mathrm{TiO}_{2}$ with different amount of wt $\%$ Pt. Their report showed that a doping level beyond the optimum doping level $(1.5 \mathrm{wt} \%$ $\mathrm{Pt}$ ) seemed to affect adversely the photocatalytic activity. Any further increase in dopant concentration could notably induce the photogenerated hole and electron recombination and decrease the photocatalytic efficiency.

The effect of halogen doping on the photocatalytic degradation of organic pollutants in $\mathrm{TiO}_{2}$ aqueous solutions has been investigated [77]. They have concluded that F has a strong enhancing effect on the photocatalytic activity, by altering the properties of $\mathrm{TiO}_{2}$ such as crystallite size, crystallinity, and phase structure. They noted that the addition of $\mathrm{F}^{-}$ions promotes the formation of anatase phase by suppressing the formation of brookite phase, subsequently forms $\equiv$ Ti-F groups, and hence, enhances the free ${ }^{\bullet} \mathrm{OH}$ radicals production and reduces the photogenerated electronhole recombination.

Yu et al. [79] studied the effect of sulfur dopant amount in the photocatalytic activity of S-doped $\mathrm{TiO}_{2}$. The photocatalytic degradation of methyl orange was studied in the presence of S-doped $\mathrm{TiO}_{2}$. In their research, they have found that the optimum loading of $S$ dopants could produce $\mathrm{TiO}_{2}$ with smaller particle size and larger surface area, which increases the formation of photogenerated electrons and thus increases the photocatalytic activity.

The foregoing notwithstanding, there are other researchers who are of the view that the presence of dopant 
TABLE 9: Effect of dopant amount on the photocatalytic activity of nano-doped- $\mathrm{TiO}_{2}$ in the photocatalytic degradation of various organic pollutants.

\begin{tabular}{|c|c|c|c|c|c|c|c|c|c|}
\hline $\begin{array}{l}\text { Type of } \\
\text { dopant }\end{array}$ & $\begin{array}{l}\text { Doped } \mathrm{TiO}_{2} \\
\text { preparation } \\
\text { method }\end{array}$ & $\begin{array}{l}\text { Range of } \\
\text { dopant } \\
\text { amount } \\
(\mathrm{wt} \%)\end{array}$ & $\begin{array}{l}\text { Optimum } \\
\text { dopant } \\
\text { concentra- } \\
\text { tion } \\
(\text { wt } \%)\end{array}$ & $\begin{array}{l}\text { Organic } \\
\text { pollutant }\end{array}$ & $\begin{array}{l}\text { Initial } \\
\text { reactant } \\
\text { concentra- } \\
\text { tion } \\
(\mathrm{mg} / \mathrm{L})\end{array}$ & $\begin{array}{l}\text { Light } \\
\text { source }\end{array}$ & $\begin{array}{l}\text { Irradiation } \\
\text { time }(\mathrm{h})\end{array}$ & $\begin{array}{l}\text { Degradation } \\
\text { efficiency } \\
(\%)\end{array}$ & Reference \\
\hline \multirow{4}{*}{$\mathrm{Fe}$} & Sol gel & $0.0-1.0$ & 0.500 & $\begin{array}{l}\text { Methyl } \\
\text { orange }\end{array}$ & 20.0 & UV-vis & 3.0 & 99.7 & {$[46]$} \\
\hline & Hydrothermal & $0.00-0.12$ & 0.090 & XRG & 100.0 & UV & 7.0 & 42 & {$[50]$} \\
\hline & $\begin{array}{l}\text { Controlled } \\
\text { hydrolysis }\end{array}$ & $0.00-0.20$ & 0.200 & $\begin{array}{l}\text { Methyl } \\
\text { orange }\end{array}$ & 20.0 & UV & 6.0 & 72 & {$[53]$} \\
\hline & $\begin{array}{l}\text { Co- } \\
\text { precipitation }\end{array}$ & $0.0-10 . .0$ & 0.017 & Phenol & 18.8 & Visible & 3.1 & 20 & {$[55]$} \\
\hline \multirow{3}{*}{$\mathrm{Pt}$} & Hydrothermal & $0.0-5.0$ & 0.001 & $\begin{array}{l}\text { Methylene } \\
\text { blue }\end{array}$ & 100.0 & UV & 1.0 & 72 & {$[51]$} \\
\hline & Impregnation & $0.0-1.6$ & 0.800 & Acid green 16 & 122.0 & UV & 1.0 & 94 & [57] \\
\hline & $\begin{array}{l}\text { Photochemical } \\
\text { reduction }\end{array}$ & $0.0-3.0$ & 1.500 & $\begin{array}{l}\text { Methyl } \\
\text { orange }\end{array}$ & 20.0 & UV & 0.5 & 88 & {$[58]$} \\
\hline $\mathrm{Pd}$ & Impregnation & $0.0-2.0$ & 0.050 & Acid green 16 & 122.0 & UV & 1.0 & 80 & {$[57]$} \\
\hline $\mathrm{Au}$ & Impregnation & $0.0-1.6$ & 0.800 & Acid green 16 & 122.0 & UV & 1.0 & 98 & {$[57]$} \\
\hline S & Hydrothermal & $0.0-2.0$ & 0.012 & $\begin{array}{l}\text { Methyl } \\
\text { orange }\end{array}$ & 20.0 & UV & 0.7 & 96 & [79] \\
\hline $\mathrm{Ce}$ & Hydrothermal & $0.0-5.0$ & 0.017 & Rhodamine B & 24.0 & UV & 2.0 & 90 & {$[62]$} \\
\hline
\end{tabular}

is not requisite for the improvement of the photocatalytic activity of $\mathrm{TiO}_{2}$. Li et al. [51] investigated the photocatalytic performance of Fe-doped $\mathrm{TiO}_{2}$ in the degradation of methylene blue. In their research, they have found that the presence of $\mathrm{Fe}$ has a suppressing influence on the photocatalytic performance of $\mathrm{TiO}_{2}$. The inhibition effect can be explained as the insertion of $\mathrm{Fe}^{3+}$ ions into the $\mathrm{TiO}_{2}$ interior matrix, which behaved as charge carrier scavengers. Probably the isolated $\mathrm{Fe}^{3+}$ ions from the surface lower the chances of trapped charge carriers and increases the recombination rate of the photogenerated electron-hole pairs. Also, Xiao et al. [63] found that undoped $\mathrm{TiO}_{2}$ showed better photocatalytic activity as compared to that Ce-doped $\mathrm{TiO}_{2}$ in the Rhodamine $\mathrm{B}$ degradation. They have found that the presence of Ce has a suppressing influence on the photocatalytic performance of $\mathrm{TiO}_{2}$. It can be explained that the partial blockage of the $\mathrm{TiO}_{2}$ active sites lowered the activation of the $\mathrm{TiO}_{2}$ catalyst particle and the collision between the active molecules and ground state molecules of $\mathrm{TiO}_{2}$, and thus, decreasing the photocatalytic activity.

Table 9 shows the effect of dopant amount on the photocatalytic degradation of various organic pollutants.

\section{Conclusions}

A comprehensive series of nano-doped- $\mathrm{TiO}_{2}$ photocatalysts are discussed in this paper. There are three main sections included: (a) the presence of various dopants (metal dopants, nonmetal dopants, halogen dopants, metalloid dopants, and co-dopants) in the formation of nano-doped- $\mathrm{TiO}_{2}$ photocatalysts, (b) the effect of the presence of dopants on the photocatalytic degradation of organic pollutants, and (c) the effects of various operating parameters on the photocatalytic degradation of organic pollutants in the presence of nanodoped- $\mathrm{TiO}_{2}$ photocatalysts. Judging from the referenced literatures, doping techniques are simple procedures used to enhance photocatalysis by $\mathrm{TiO}_{2}$. Desirable characteristics such as small crystallite size, high specific surface area, and the presence of the anatase phase are easily achieved by doping techniques. Nevertheless, the mechanisms underlying doped $\mathrm{TiO}_{2}$ are still unclear. The relationship between the photocatalytic activity and physical properties of $\mathrm{TiO}_{2}$ requires further study to arrive at optimal conditions for the photocatalytic degradation of various organic pollutants.

\section{Acknowledgments}

The authors gratefully acknowledge the Universiti Sains Malaysia and the Ministry of Science, Technology and Innovation of Malaysia for giving support and funding in the form of USM Fellowship, Research University Grant (1001/PJKIMIA/811068), and Postgraduate Research Grant Scheme (1001/PJKIMIA/8033051).

\section{References}

[1] U. M. Gaya and A. H. Abdullah, "Heterogeneous photocatalytic degradation of organic contaminants over titanium dioxide: a review of fundamentals, progress and problems," Journal of Photochemistry and Photobiology C, vol. 9, no. 1, pp. 1-12, 2007.

[2] A. Di Paola, G. Cufalo, M. Addamo et al., "Photocatalytic activity of nanocrystalline $\mathrm{TiO}_{2}$ (brookite, rutile and 
brookite-based) powders prepared by thermohydrolysis of $\mathrm{TiCl}_{4}$ in aqueous chloride solutions," Colloids and Surfaces A, vol. 317, no. 1-3, pp. 366-376, 2008.

[3] H. Yu, J. Yu, B. Cheng, and J. Lin, "Synthesis, characterization and photocatalytic activity of mesoporous titania nanorod/titanate nanotube composites," Journal of Hazardous Materials, vol. 147, no. 1-2, pp. 581-587, 2007.

[4] S. Nagamine, A. Sugioka, H. Iwamoto, and Y. Konishi, "Formation of $\mathrm{TiO}_{2}$ hollow microparticles by spraying water droplets into an organic solution of titanium tetraisopropoxide (TTIP)—effects of TTIP concentration and TTIPprotecting additives," Powder Technology, vol. 186, no. 2, pp. 168-175, 2008.

[5] J. Yu, G. Wang, B. Cheng, and M. Zhou, "Effects of hydrothermal temperature and time on the photocatalytic activity and microstructures of bimodal mesoporous $\mathrm{TiO}_{2}$ powders," Applied Catalysis B, vol. 69, no. 3-4, pp. 171-180, 2007.

[6] J. H. Lee and Y. S. Yang, "Effect of $\mathrm{HCl}$ concentration and reaction time on the change in the crystalline state of $\mathrm{TiO}_{2}$ prepared from aqueous TiCl4 solution by precipitation," Journal of the European Ceramic Society, vol. 25, no. 16, pp. 3573-3578, 2005.

[7] A. Verma, A. K. Bakhshi, and S. A. Agnihotry, "Effect of different precursor sols on the properties of $\mathrm{CeO}_{2}-\mathrm{TiO}_{2}$ films for electrochromic window applications," Electrochimica Acta, vol. 51, no. 22, pp. 4639-4648, 2006.

[8] W. Zhang, L. Zou, and L. Wang, "Photocatalytic $\mathrm{TiO}_{2}$ /adsorbent nanocomposites prepared via wet chemical impregnation for wastewater treatment: a review," Applied Catalysis A, vol. 371, no. 1-2, pp. 1-9, 2009.

[9] A. Orendorz, A. Brodyanski, J. Lösch et al., "Phase transformation and particle growth in nanocrystalline anatase $\mathrm{TiO}_{2}$ films analyzed by X-ray diffraction and Raman spectroscopy," Surface Science, vol. 601, no. 18, pp. 4390-4394, 2007.

[10] N. Venkatachalam, M. Palanichamy, and V. Murugesan, "Solgel preparation and characterization of alkaline earth metal doped nano $\mathrm{TiO}_{2}$ : efficient photocatalytic degradation of 4chlorophenol," Journal of Molecular Catalysis A, vol. 273, no. 1-2, pp. 177-185, 2007.

[11] J. Y. Kim, C. S. Kim, H. K. Chang, and T. O. Kim, "Synthesis and characterization of $\mathrm{N}$-doped $\mathrm{TiO}_{2} / \mathrm{ZrO}_{2}$ visible light photocatalysts," Advanced Powder Technology, vol. 22, no. 3, pp. 443-448, 2011.

[12] X. T. Zhang, K. Udagawa, Z. Y. Liu et al., "Photocatalytic and photoelectrochemical studies on $\mathrm{N}$-doped $\mathrm{TiO}_{2}$ photocatalyst," Journal of Photochemistry and Photobiology A, vol. 202, no. 1, pp. 39-47, 2009.

[13] D. Wu, M. Long, W. Cai, C. Chen, and Y. Wu, "Low temperature hydrothermal synthesis of $\mathrm{N}$-doped $\mathrm{TiO}_{2}$ photocatalyst with high visible-light activity," Journal of Alloys and Compounds, vol. 502, no. 2, pp. 289-294, 2010.

[14] D. G. Huang, S. J. Liao, J. M. Liu, Z. Dang, and L. Petrik, "Preparation of visible-light responsive N-F-codoped $\mathrm{TiO}_{2}$ photocatalyst by a sol-gel-solvothermal method," Journal of Photochemistry and Photobiology A, vol. 184, no. 3, pp. 282288, 2006.

[15] C. Wen, H. Deng, J. Y. Tian, and J. M. Zhang, "Photocatalytic activity enhancing for $\mathrm{TiO}_{2}$ photocatalyst by doping with $\mathrm{La}$," Transactions of Nonferrous Metals Society of China, vol. 16, pp. s728-s731, 2006.

[16] C.-H. Chang and Y.-H. Shen, "Synthesis and characterization of chromium doped $\mathrm{SrTiO}_{3}$ photocatalyst," Materials Letters, vol. 60, no. 1, pp. 129-132, 2006.
[17] S. X. Liu and X. Y. Chen, "A visible light response $\mathrm{TiO}_{2}$ photocatalyst realized by cationic S-doping and its application for phenol degradation," Journal of Hazardous Materials, vol. 152, no. 1, pp. 48-55, 2008.

[18] A. Kubacka, G. Colón, and M. Fernández-García, "Cationic ( $\mathrm{V}, \mathrm{Mo}, \mathrm{Nb}, \mathrm{W})$ doping of $\mathrm{TiO}_{2}$-anatase: a real alternative for visible light-driven photocatalysts," Catalysis Today, vol. 143, no. 3-4, pp. 286-292, 2009.

[19] H. Cai, G. Liu, W. Lü, X. Li, L. Yu, and D. Li, "Effect of Hodoping on photocatalytic activity of nanosized $\mathrm{TiO}_{2}$ catalyst," Journal of Rare Earths, vol. 26, no. 1, pp. 71-75, 2008.

[20] E. Setiawati and K. Kawano, "Stabilization of anatase phase in the rare earth; Eu and Sm ion doped nanoparticle $\mathrm{TiO}_{2}$," Journal of Alloys and Compounds, vol. 451, no. 1-2, pp. 293296, 2008.

[21] K. Pirkanniemi and M. Sillanpää, "Heterogeneous water phase catalysis as an environmental application: a review," Chemosphere, vol. 48, no. 10, pp. 1047-1060, 2002.

[22] J. Nowotny, T. Bak, M. K. Nowotny, and L. R. Sheppard, "Titanium dioxide for solar-hydrogen I. Functional properties," International Journal of Hydrogen Energy, vol. 32, no. 14, pp. 2609-2629, 2007.

[23] J. A. Rengifo-Herrera, K. Pierzchala, A. Sienkiewicz, L. Forró, J. Kiwi, and C. Pulgarin, "Abatement of organics and Escherichia coli by N, S co-doped $\mathrm{TiO}_{2}$ under UV and visible light. Implications of the formation of singlet oxygen $\left({ }^{1} \mathrm{O}_{2}\right)$ under visible light," Applied Catalysis B, vol. 88, no. 3-4, pp. 398-406, 2009.

[24] J. J. Carvajal, V. Nikolov, R. Solé et al., "Crystallization region, crystal growth, and characterization of rubidium titanyl phosphate codoped with niobium and lanthanide ions," Chemistry of Materials, vol. 14, no. 7, pp. 3136-3142, 2002.

[25] P. Supphasrirongjaroen, P. Praserthdam, J. Panpranot, D. NaRanong, and O. Mekasuwandumrong, "Effect of quenching medium on photocatalytic activity of nano- $\mathrm{TiO}_{2}$ prepared by solvothermal method," Chemical Engineering Journal, vol. 138, no. 1-3, pp. 622-627, 2008.

[26] O. Carp, C. L. Huisman, and A. Reller, "Photoinduced reactivity of titanium dioxide," Progress in Solid State Chemistry, vol. 32, no. 1-2, pp. 33-177, 2004.

[27] A. Kudo, R. Niishiro, A. Iwase, and H. Kato, "Effects of doping of metal cations on morphology, activity, and visible light response of photocatalysts," Chemical Physics, vol. 339, no. 13, pp. 104-110, 2007.

[28] X. Wang, S. Meng, X. Zhang, H. Wang, W. Zhong, and Q. Du, "Multi-type carbon doping of $\mathrm{TiO}_{2}$ photocatalyst," Chemical Physics Letters, vol. 444, no. 4-6, pp. 292-296, 2007.

[29] X. Fan, X. Chen, S. Zhu et al., "The structural, physical and photocatalytic properties of the mesoporous Cr-doped $\mathrm{TiO}_{2}$," Journal of Molecular Catalysis A, vol. 284, no. 1-2, pp. 155-160, 2008.

[30] E. György, G. Socol, E. Axente, I. N. Mihailescu, C. Ducu, and S. Ciuca, "Anatase phase $\mathrm{TiO}_{2}$ thin films obtained by pulsed laser deposition for gas sensing applications," Applied Surface Science, vol. 247, no. 1-4, pp. 429-433, 2005.

[31] D. S. Kim, S. J. Han, and S.-Y. Kwak, "Synthesis and photocatalytic activity of mesoporous $\mathrm{TiO}_{2}$ with the surface area, crystallite size, and pore size," Journal of Colloid and Interface Science, vol. 316, no. 1, pp. 85-91, 2007.

[32] A. R. Liu, S. M. Wang, Y. R. Zhao, and Z. Zheng, "Lowtemperature preparation of nanocrystalline $\mathrm{TiO}_{2}$ photocatalyst with a very large specific surface area," Materials Chemistry and Physics, vol. 99, no. 1, pp. 131-134, 2006. 
[33] W. Kongsuebchart, P. Praserthdam, J. Panpranot, A. Sirisuk, P. Supphasrirongjaroen, and C. Satayaprasert, "Effect of crystallite size on the surface defect of nano- $\mathrm{TiO}_{2}$ prepared via solvothermal synthesis," Journal of Crystal Growth, vol. 297, no. 1, pp. 234-238, 2006.

[34] M. Hirano, C. Nakahara, K. Ota, O. Tanaike, and M. Inagaki, "Photoactivity and phase stability of $\mathrm{ZrO}_{2}$-doped anatasetype $\mathrm{TiO}_{2}$ directly formed as nanometer-sized particles by hydrolysis under hydrothermal conditions," Journal of Solid State Chemistry, vol. 170, no. 1, pp. 39-47, 2003.

[35] L. G. Devi, B. N. Murthy, and S. G. Kumar, "Photocatalytic activity of $\mathrm{TiO}_{2}$ doped with $\mathrm{Zn}^{2+}$ and $\mathrm{V}^{5+}$ transition metal ions: influence of crystallite size and dopant electronic configuration on photocatalytic activity," Materials Science and Engineering B, vol. 166, no. 1, pp. 1-6, 2010.

[36] M. S. Nahar, J. Zhang, K. Hasegawa, S. Kagaya, and S. Kuroda, "Phase transformation of anatase-rutile crystals in doped and undoped $\mathrm{TiO}_{2}$ particles obtained by the oxidation of polycrystalline sulfide," Materials Science in Semiconductor Processing, vol. 12, no. 4-5, pp. 168-174, 2009.

[37] G. Q. Li, C. Y. Liu, and Y. Liu, "Different effects of cerium ions doping on properties of anatase and rutile $\mathrm{TiO}_{2}$," Applied Surface Science, vol. 253, no. 5, pp. 2481-2486, 2006.

[38] C.-T. Hsieh, W.-S. Fan, W.-Y. Chen, and J.-Y. Lin, "Adsorption and visible-light-derived photocatalytic kinetics of organic dye on Co-doped titania nanotubes prepared by hydrothermal synthesis," Separation and Purification Technology, vol. 67, no. 3, pp. 312-318, 2009.

[39] K. Suriye, P. Praserthdam, and B. Jongsomjit, "Impact of Ti3+ present in titania on characteristics and catalytic properties of the $\mathrm{Co} / \mathrm{TiO}_{2}$ catalyst," Industrial and Engineering Chemistry Research, vol. 44, no. 17, pp. 6599-6604, 2005.

[40] M. Atashfaraz, M. Shariaty-Niassar, S. Ohara et al., "Effect of titanium dioxide solubility on the formation of $\mathrm{BaTiO}_{3}$ nanoparticles in supercritical water," Fluid Phase Equilibria, vol. 257, no. 2, pp. 233-237, 2007.

[41] K. J. Zhang, W. Xu, X. J. Li, S. J. Zheng, G. Xu, and J. H. Wang, "Photocatalytic oxidation activity of titanium dioxide film enhanced by Mn non-uniform doping," Transactions of Nonferrous Metals Society of China, vol. 16, no. 5, pp. 10691075, 2006.

[42] M. Wang, G. Song, J. Li, L. Miao, and B. Zhang, "Direct hydrothermal synthesis and magnetic property of titanate nanotubes doped magnetic metal ions," Journal of University of Science and Technology Beijing, vol. 15, no. 5, pp. 644-648, 2008.

[43] R.-F. Chen, C.-X. Zhang, J. Deng, and G.-Q. Song, "Preparation and photocatalytic activity of $\mathrm{Cu}^{2+}$-doped $\mathrm{TiO}_{2} / \mathrm{SiO}_{2}$," International Journal of Minerals, Metallurgy and Materials, vol. 16, no. 2, pp. 220-225, 2009.

[44] J.-C. Xu, M. Lu, X.-Y. Guo, and H.-L. Li, "Zinc ions surfacedoped titanium dioxide nanotubes and its photocatalysis activity for degradation of methyl orange in water," Journal of Molecular Catalysis A, vol. 226, no. 1, pp. 123-127, 2005.

[45] R. Janes, L. J. Knightley, and C. J. Harding, "Structural and spectroscopic studies of iron (III) doped titania powders prepared by sol-gel synthesis and hydrothermal processing," Dyes and Pigments, vol. 62, no. 3, pp. 199-212, 2004.

[46] L. Deng, S. Wang, D. Liu et al., "Synthesis, characterization of Fe-doped $\mathrm{TiO}_{2}$ nanotubes with high photocatalytic activity," Catalysis Letters, vol. 129, no. 3-4, pp. 513-518, 2009.

[47] C. C. Tsai and H. Teng, "Chromium-doped titanium dioxide thin-film photoanodes in visible-light-induced waterli cleavage," Applied Surface Science, vol. 254, no. 15, pp. 49124918, 2008.

[48] C.-G. Wu, C.-C. Chao, and F.-T. Kuo, "Enhancement of the photo catalytic performance of $\mathrm{TiO}_{2}$ catalysts via transition metal modification," Catalysis Today, vol. 97, no. 2-3, pp. 103-112, 2004.

[49] M. Asiltürk, F. Sayilkan, and E. Arpaç, "Effect of Fe3+ ion doping to $\mathrm{TiO}_{2}$ on the photocatalytic degradation of Malachite Green dye under UV and vis-irradiation," Journal of Photochemistry and Photobiology A, vol. 203, no. 1, pp. 6471, 2009.

[50] J. Zhu, W. Zheng, B. He, J. Zhang, and M. Anpo, "Characterization of $\mathrm{Fe}-\mathrm{TiO}_{2}$ photocatalysts synthesized by hydrothermal method and their photocatalytic reactivity for photodegradation of XRG dye diluted in water," Journal of Molecular Catalysis A, vol. 216, no. 1, pp. 35-43, 2004.

[51] Z. Li, W. Shen, W. He, and X. Zu, "Effect of Fe-doped $\mathrm{TiO}_{2}$ nanoparticle derived from modified hydrothermal process on the photocatalytic degradation performance on methylene blue," Journal of Hazardous Materials, vol. 155, no. 3, pp. 590-594, 2008.

[52] C. Adán, J. Carbajo, A. Bahamonde, and A. MartínezArias, "Phenol photodegradation with oxygen and hydrogen peroxide over $\mathrm{TiO}_{2}$ and Fe-doped $\mathrm{TiO}_{2}$," Catalysis Today, vol. 143, no. 3-4, pp. 247-252, 2009.

[53] T. Tong, J. Zhang, B. Tian, F. Chen, and D. He, "Preparation of $\mathrm{Fe}^{3+}$-doped $\mathrm{TiO}_{2}$ catalysts by controlled hydrolysis of titanium alkoxide and study on their photocatalytic activity for methyl orange degradation," Journal of Hazardous Materials, vol. 155 , no. 3, pp. 572-579, 2008.

[54] W. C. Hung, S. H. Fu, J. J. Tseng, H. Chu, and T. H. Ko, “Study on photocatalytic degradation of gaseous dichloromethane using pure and iron ion-doped $\mathrm{TiO}_{2}$ prepared by the sol-gel method," Chemosphere, vol. 66, no. 11, pp. 2142-2151, 2007.

[55] Z. Ambrus, N. Balázs, T. Alapi et al., "Synthesis, structure and photocatalytic properties of $\mathrm{Fe}(\mathrm{III})$-doped $\mathrm{TiO}_{2}$ prepared from TiCl3," Applied Catalysis B, vol. 81, no. 1-2, pp. 27-37, 2008.

[56] G. Colón, M. C. Hidalgo, J. A. Navío, E. P. Melián, O. G. Díaz, and J. M. Doña, "Influence of amine template on the photoactivity of $\mathrm{TiO}_{2}$ nanoparticles obtained by hydrothermal treatment," Applied Catalysis B, vol. 78, no. 12, pp. 176-182, 2008.

[57] S. Sakthivel, M. V. Shankar, M. Palanichamy, B. Arabindoo, D. W. Bahnemann, and V. Murugesan, "Enhancement of photocatalytic activity by metal deposition: characterisation and photonic efficiency of $\mathrm{Pt}, \mathrm{Au}$ and $\mathrm{Pd}$ deposited on $\mathrm{TiO}_{2}$ catalyst," Water Research, vol. 38, no. 13, pp. 3001-3008, 2004.

[58] M. Huang, C. Xu, Z. Wu, Y. Huang, J. Lin, and J. Wu, "Photocatalytic discolorization of methyl orange solution by $\mathrm{Pt}$ modified $\mathrm{TiO}_{2}$ loaded on natural zeolite," Dyes and Pigments, vol. 77, no. 2, pp. 327-334, 2008.

[59] Y. Ishibai, J. Sato, T. Nishikawa, and S. Miyagishi, "Synthesis of visible-light active $\mathrm{TiO}_{2}$ photocatalyst with Ptmodification: role of $\mathrm{TiO}_{2}$ substrate for high photocatalytic activity," Applied Catalysis B, vol. 79, no. 2, pp. 117-121, 2008.

[60] W. Sun, S. Zhang, Z. Liu, C. Wang, and Z. Mao, "Studies on the enhanced photocatalytic hydrogen evolution over Pt/PEG-modified $\mathrm{TiO}_{2}$ photocatalysts," International Journal of Hydrogen Energy, vol. 33, no. 4, pp. 1112-1117, 2008.

[61] H. Abe, T. Kimitani, and M. Naito, "Influence of NH3/Ar plasma irradiation on physical and photocatalytic properties 
of $\mathrm{TiO}_{2}$ nanopowder," Journal of Photochemistry and Photobiology A, vol. 183, no. 1-2, pp. 171-175, 2006.

[62] M. Bettinelli, V. Dallacasa, D. Falcomer et al., "Photocatalytic activity of $\mathrm{TiO}_{2}$ doped with boron and vanadium," Journal of Hazardous Materials, vol. 146, no. 3, pp. 529-534, 2007.

[63] J. R. Xiao, T. Y. Peng, R. Li, Z. H. Peng, and C. H. Yan, "Preparation, phase transformation and photocatalytic activities of cerium-doped mesoporous titania nanoparticles," Journal of Solid State Chemistry, vol. 179, no. 4, pp. 1161-1170, 2006.

[64] E. A. Kozlova and A. V. Vorontsov, "Influence of mesoporous and platinum-modified titanium dioxide preparation methods on photocatalytic activity in liquid and gas phase," Applied Catalysis B, vol. 77, no. 1-2, pp. 35-45, 2007.

[65] C. Wang, Y. H. Ao, P. F. Wang, J. Hou, J. Qian, and S. H. Zhang, "Preparation, characterization, photocatalytic properties of titania hollow sphere doped with cerium," Journal of Hazardous Materials, vol. 178, no. 1-3, pp. 517-521, 2010.

[66] J. J. Xu, Y. H. Ao, M. D. Chen, and D. G. Fu, "Lowtemperature preparation of Boron-doped titania by hydrothermal method and its photocatalytic activity," Journal of Alloys and Compounds, vol. 484, no. 1-2, pp. 73-79, 2009.

[67] C. Jin, R. Y. Zheng, Y. Guo, J. L. Xie, Y. X. Zhu, and Y. C. Xie, "Hydrothermal synthesis and characterization of phosphorous-doped $\mathrm{TiO}_{2}$ with high photocatalytic activity for methylene blue degradation," Journal of Molecular Catalysis A, vol. 313, no. 1-2, pp. 44-48, 2009.

[68] K. J. A. Raj, A. V. Ramaswamy, and B. Viswanathan, "Surface area, pore size, and particle size engineering of titania with seeding technique and phosphate modification," Journal of Physical Chemistry C, vol. 113, no. 31, pp. 13750-13757, 2009.

[69] F. Peng, L. F. Cai, L. Huang, H. Yu, and H. J. Wang, "Preparation of nitrogen-doped titanium dioxide with visible-light photocatalytic activity using a facile hydrothermal method," Journal of Physics and Chemistry of Solids, vol. 69, no. 7, pp. 1657-1664, 2008.

[70] J. Senthilnathan and L. Philip, "Photocatalytic degradation of lindane under UV and visible light using $\mathrm{N}$-doped $\mathrm{TiO}_{2}$," Chemical Engineering Journal, vol. 161, no. 1-2, pp. 83-92, 2010.

[71] H. Tian, J. Ma, K. Li, and J. Li, "Hydrothermal synthesis of Sdoped $\mathrm{TiO}_{2}$ nanoparticles and their photocatalytic ability for degradation of methyl orange," Ceramics International, vol. 35, no. 3, pp. 1289-1292, 2009.

[72] W. K. Ho, J. C. Yu, and S. C. Lee, "Low-temperature hydrothermal synthesis of S-doped $\mathrm{TiO}_{2}$ with visible light photocatalytic activity," Journal of Solid State Chemistry, vol. 179, no. 4, pp. 1171-1176, 2006.

[73] X. Chen and S. S. Mao, "Titanium dioxide nanomaterials: synthesis, properties, modifications and applications," Chemical Reviews, vol. 107, no. 7, pp. 2891-2959, 2007.

[74] S. Livraghi, K. Elghniji, A. M. Czoska, M. C. Paganini, E. Giamello, and M. Ksibi, "Nitrogen-doped and nitrogenfluorine-codoped titanium dioxide. Nature and concentration of the photoactive species and their role in determining the photocatalytic activity under visible light," Journal of Photochemistry and Photobiology A, vol. 205, no. 2-3, pp. 9397, 2009.

[75] J. G. Yu, W. G. Wang, B. Cheng, and B. L. Su, "Enhancement of photocatalytic activity of Mesporous $\mathrm{TiO}_{2}$ powders by hydrothermal surface fluorination treatment," Journal of Physical Chemistry C, vol. 113, no. 16, pp. 6743-6750, 2009.

[76] S. Hu, A. Wang, X. Li, and H. Löwe, "Hydrothermal synthesis of well-dispersed ultrafine $\mathrm{N}$-doped $\mathrm{TiO} 2$ nanoparticles with enhanced photocatalytic activity under visible light," Journal of Physics and Chemistry of Solids, vol. 71, no. 3, pp. 156-162, 2010.

[77] H. Sun, S. Wang, H. M. Ang, M. O. Tadé, and Q. Li, "Halogen element modified titanium dioxide for visible light photocatalysis," Chemical Engineering Journal, vol. 162, no. 2, pp. 437-447, 2010.

[78] K. Mori, K. Maki, S. Kawasaki, S. Yuan, and H. Yamashita, "Hydrothermal synthesis of $\mathrm{TiO}_{2}$ photocatalysts in the presence of NH4 F and their application for degradation of organic compounds," Chemical Engineering Science, vol. 63, no. 20 , pp. 5066-5070, 2008.

[79] C. L. Yu, J. C. Yu, and M. Chan, "Sonochemical fabrication of fluorinated mesoporous titanium dioxide microspheres," Journal of Solid State Chemistry, vol. 182, no. 5, pp. 10611069, 2009.

[80] N. Todorova, T. Giannakopoulou, T. Vaimakis, and C. Trapalis, "Structure tailoring of fluorine-doped $\mathrm{TiO}_{2}$ nanostructured powders," Materials Science and Engineering B, vol. 152, no. 1-3, pp. 50-54, 2008.

[81] J. Xu, Y. Ao, D. Fu, and C. Yuan, "Synthesis of fluorine-doped titania-coated activated carbon under low temperature with high photocatalytic activity under visible light," Journal of Physics and Chemistry of Solids, vol. 69, no. 10, pp. 23662370, 2008.

[82] A. Zaleska, J. W. Sobczak, E. Grabowska, and J. Hupka, "Preparation and photocatalytic activity of boron-modified $\mathrm{TiO}_{2}$ under UV and visible light," Applied Catalysis B, vol. 78, no. 1-2, pp. 92-100, 2008.

[83] E. Grabowska, A. Zaleska, J. W. Sobczak, M. Gazda, and J. Hupka, "Boron-doped $\mathrm{TiO}_{2}$ : characteristics and photoactivity under visible light," Procedia Chemistry, vol. 1, no. 2, pp. 1553-1559, 2009.

[84] M. Estruga, C. Domingo, X. Domènech, and J. A. Ayllón, "Zirconium-doped and silicon-doped $\mathrm{TiO}_{2}$ photocatalysts synthesis from ionic-liquid-like precursors," Journal of Colloid and Interface Science, vol. 344, no. 2, pp. 327-333, 2010.

[85] R. Jin, Z. Wu, Y. Liu, B. Jiang, and H. Wang, "Photocatalytic reduction of $\mathrm{NO}$ with $\mathrm{NH}_{3}$ using Si-doped $\mathrm{TiO}_{2}$ prepared by hydrothermal method," Journal of Hazardous Materials, vol. 161, no. 1, pp. 42-48, 2009.

[86] C. He, B. Tian, and J. Zhang, "Thermally stable $\mathrm{SiO}_{2}$ doped mesoporous anatase $\mathrm{TiO}_{2}$ with large surface area and excellent photocatalytic activity," Journal of Colloid and Interface Science, vol. 344, no. 2, pp. 382-389, 2010.

[87] D. Li, H. Haneda, N. K. Labhsetwar, S. Hishita, and N. Ohashi, "Visible-light-driven photocatalysis on fluorine-doped $\mathrm{TiO}_{2}$ powders by the creation of surface oxygen vacancies," Chemical Physics Letters, vol. 401, no. 4-6, pp. 579-584, 2005.

[88] Q. Zhang, Y. Li, E. A. Ackerman, M. Gajdardziska-Josifovska, and $\mathrm{H}$. Li, "Visible light responsive iodine-doped $\mathrm{TiO}_{2}$ for photocatalytic reduction of $\mathrm{CO}_{2}$ to fuels," Applied Catalysis A, vol. 400, no. 1-2, pp. 195-202, 2011.

[89] W.-A. Wang, Q. Shi, Y.-P. Wang, J.-L. Cao, G.-Q. Liu, and P.Y. Peng, "Preparation and characterization of iodine-doped mesoporous $\mathrm{TiO}_{2}$ by hydrothermal method," Applied Surface Science, vol. 257, no. 8, pp. 3688-3696, 2011.

[90] Y. Ma, J.-W. Fu, X. Tao, X. Li, and J.-F. Chen, "Low temperature synthesis of iodine-doped $\mathrm{TiO}_{2}$ nanocrystallites with enhanced visible-induced photocatalytic activity," Applied Surface Science, vol. 257, no. 11, pp. 5046-5051, 2011.

[91] R. Long, Y. Dai, and B. Huang, "Structural and electronic properties of iodine-doped anatase and rutile $\mathrm{TiO}_{2}$," Computational Materials Science, vol. 45, no. 2, pp. 223-228, 2009. 
[92] N. Lu, H. Zhao, J. Li, X. Quan, and S. Chen, "Characterization of boron-doped $\mathrm{TiO}_{2}$ nanotube arrays prepared by electrochemical method and its visible light activity," Separation and Purification Technology, vol. 62, no. 3, pp. 668-673, 2008.

[93] W. Shi, Q. Chen, Y. Xu, D. Wu, and C.-F. Huo, "Investigation of the silicon concentration effect on Si-doped anatase $\mathrm{TiO}_{2}$ by first-principles calculation," Journal of Solid State Chemistry, vol. 184, no. 8, pp. 1983-1988, 2011.

[94] C. Wen, Y. J. Zhu, T. Kanbara, H. Z. Zhu, and C. F. Xiao, "Effects of I and $\mathrm{F}$ codoped $\mathrm{TiO}_{2}$ on the photocatalytic degradation of methylene blue," Desalination, vol. 249, no. 2, pp. 621-625, 2009.

[95] R. Niishiro, R. Konta, H. Kato, W. J. Chun, K. Asakura, and A. Kudo, "Photocatalytic $\mathrm{O}_{2}$ evolution of rhodium and antimony-codoped rutile-type $\mathrm{TiO}_{2}$ under visible light irradiation," Journal of Physical Chemistry C, vol. 111, no. 46, pp. 17420-17426, 2007.

[96] Y. F. Ma, J. L. Zhang, B. Z. Tian, F. Chen, and L. Z. Wang, "Synthesis and characterization of thermally stable Sm,N co-doped $\mathrm{TiO}_{2}$ with highly visible light activity," Journal of Hazardous Materials, vol. 182, no. 1-3, pp. 386-393, 2010.

[97] C. R. Estrellan, C. Salim, and H. Hinode, "Photocatalytic decomposition of perfluorooctanoic acid by iron and niobium co-doped titanium dioxide," Journal of Hazardous Materials, vol. 179, no. 1-3, pp. 79-83, 2010.

[98] J. X. Li, J. H. Xu, W.-L. Dai, H. Li, and K. Fan, "Onepot synthesis of twist-like helix tungsten-nitrogen-codoped titania photocatalysts with highly improved visible light activity in the abatement of phenol," Applied Catalysis B, vol. 82, no. 3-4, pp. 233-243, 2008.

[99] R. Khan, S. W. Kim, T.-J. Kim, and C.-M. Nam, "Comparative study of the photocatalytic performance of boron-iron Co-doped and boron-doped $\mathrm{TiO}_{2}$ nanoparticles," Materials Chemistry and Physics, vol. 112, no. 1, pp. 167-172, 2008.

[100] J. G. Yu, M. H. Zhou, B. Cheng, and X. J. Zhao, "Preparation, characterization and photocatalytic activity of in situ N,Scodoped $\mathrm{TiO}_{2}$ powders," Journal of Molecular Catalysis A, vol. 246, no. 1-2, pp. 176-184, 2006.

[101] C. Yu, D. Cai, K. Yang, J. C. Yu, Y. Zhou, and C. Fan, "Solgel derived S,I-codoped mesoporous $\mathrm{TiO}_{2}$ photocatalyst with high visible-light photocatalytic activity," Journal of Physics and Chemistry of Solids, vol. 71, no. 9, pp. 1337-1343, 2010.

[102] F. Wei, L. Ni, and P. Cui, "Preparation and characterization of N-S-codoped $\mathrm{TiO}_{2}$ photocatalyst and its photocatalytic activity," Journal of Hazardous Materials, vol. 156, no. 1-3, pp. 135-140, 2008.

[103] M. Hamadanian, A. Reisi-Vanani, and A. Majedi, "Synthesis, characterization and effect of calcination temperature on phase transformation and photocatalytic activity of $\mathrm{Cu}, \mathrm{S}$ codoped $\mathrm{TiO}_{2}$ nanoparticles," Applied Surface Science, vol. 256, no. 6, pp. 1837-1844, 2010.

[104] Y. Xie, X. J. Zhao, Y. Z. Li, Q. N. Zhao, X. D. Zhou, and Q. Yuan, "CTAB-assisted synthesis of mesoporous F-N-codoped $\mathrm{TiO}_{2}$ powders with high visible-light-driven catalytic activity and adsorption capacity," Journal of Solid State Chemistry, vol. 181, no. 8, pp. 1936-1942, 2008.

[105] L. Y. Li, Z. Y. Xu, F. L. Liu et al., "Photocatalytic nitrate reduction over $\mathrm{Pt}-\mathrm{Cu} / \mathrm{TiO}_{2}$ catalysts with benzene as hole scavenger," Journal of Photochemistry and Photobiology A, vol. 212, no. 2-3, pp. 113-121, 2010.

[106] Y. Wu, J. Zhang, L. Xiao, and F. Chen, "Properties of carbon and iron modified $\mathrm{TiO}_{2}$ photocatalyst synthesized at low temperature and photodegradation of acid orange 7 under visible light," Applied Surface Science, vol. 256, no. 13, pp. 4260-4268, 2010.

[107] T. Sreethawong, S. Laehsalee, and S. Chavadej, "Use of Pt/Ndoped mesoporous-assembled nanocrystalline $\mathrm{TiO}_{2}$ for photocatalytic $\mathrm{H}_{2}$ production under visible light irradiation," Catalysis Communications, vol. 10, no. 5, pp. 538-543, 2009.

[108] S. K. Biswas, A. Pathak, N. K. Pramanik, D. Dhak, and P. Pramanik, "Codoped $\mathrm{Cr}$ and $\mathrm{W}$ rutile nanosized powders obtained by pyrolysis of triethanolamine complexes," Ceramics International, vol. 34, no. 8, pp. 1875-1883, 2008.

[109] G. Colón, M. Maicu, M. C. Hidalgo, J. A. Navío, A. Kubacka, and M. Fernández-García, "Gas phase photocatalytic oxidation of toluene using highly active Pt doped $\mathrm{TiO}_{2}$," Journal of Molecular Catalysis A, vol. 320, no. 1-2, pp. 14-18, 2010.

[110] N. A. Jamalluddin and A. Z. Abdullah, "Reactive dye degradation by combined $\mathrm{Fe}(\mathrm{III}) / \mathrm{TiO}_{2}$ catalyst and ultrasonic irradiation: effect of $\mathrm{Fe}(\mathrm{III})$ loading and calcination temperature," Ultrasonics Sonochemistry, vol. 18, no. 2, pp. 669-678, 2011.

[111] C. H. Chiou and R. S. Juang, "Photocatalytic degradation of phenol in aqueous solutions by $\mathrm{Pr}$-doped $\mathrm{TiO}_{2}$ nanoparticles," Journal of Hazardous Materials, vol. 149, no. 1, pp. 1-7, 2007.

[112] C. Suwanchawalit and S. Wongnawa, "Influence of calcination on the microstructures and photocatalytic activity of potassium oxalate-doped $\mathrm{TiO}_{2}$ powders," Applied Catalysis A, vol. 338, no. 1-2, pp. 87-99, 2008.

[113] T. J. Kemp and R. A. McIntyre, "Transition metal-doped titanium(IV) dioxide: characterisation and influence on photodegradation of poly(vinyl chloride)," Polymer Degradation and Stability, vol. 91, no. 1, pp. 165-194, 2006.

[114] L. Andronic, A. Enesca, C. Vladuta, and A. Duta, "Photocatalytic activity of cadmium doped $\mathrm{TiO}_{2}$ films for photocatalytic degradation of dyes," Chemical Engineering Journal, vol. 152, no. 1, pp. 64-71, 2009.

[115] C. Sahoo, A. K. Gupta, and A. Pal, "Photocatalytic degradation of Crystal Violet (C.I. Basic Violet 3) on silver ion doped $\mathrm{TiO}_{2}$," Dyes and Pigments, vol. 66, no. 3, pp. 189-196, 2005.

[116] Q. Xiao, J. Zhang, C. Xiao, Z. Si, and X. Tan, "Solar photocatalytic degradation of methylene blue in carbon-doped $\mathrm{TiO}_{2}$ nanoparticles suspension," Solar Energy, vol. 82, no. 8, pp. 706-713, 2008.

[117] S. Yang, W. Zhu, J. Wang, and Z. Chen, "Catalytic wet air oxidation of phenol over $\mathrm{CeO}_{2}-\mathrm{TiO}_{2}$ catalyst in the batch reactor and the packed-bed reactor," Journal of Hazardous Materials, vol. 153, no. 3, pp. 1248-1253, 2008.

[118] L. G. Devi and K. E. Rajashekhar, "A kinetic model based on non-linear regression analysis is proposed for the degradation of phenol under UV/solar light using nitrogen doped $\mathrm{TiO}_{2}$," Journal of Molecular Catalysis A, vol. 334, no. 1-2, pp. 65-76, 2011.

[119] Y. Lv, L. Yu, H. Huang, H. Liu, and Y. Feng, "Preparation, characterization of P-doped $\mathrm{TiO}_{2}$ nanoparticles and their excellent photocatalystic properties under the solar light irradiation," Journal of Alloys and Compounds, vol. 488, no. 1, pp. 314-319, 2009.

[120] J. Gong, C. Yang, W. Pu, and J. Zhang, "Liquid phase deposition of tungsten doped $\mathrm{TiO}_{2}$ films for visible light photoelectrocatalytic degradation of dodecyl-benzenesulfonate," Chemical Engineering Journal, vol. 167, no. 1, pp. 190-197, 2011.

[121] N. Venkatachalam, M. Palanichamy, B. Arabindoo, and V. Murugesan, "Enhanced photocatalytic degradation of 
4-chlorophenol by $\mathrm{Zr}^{4+}$ doped nano $\mathrm{TiO}_{2}$," Journal of Molecular Catalysis A, vol. 266, no. 1-2, pp. 158-165, 2007.

[122] J. Sun, X. Wang, J. Sun, R. Sun, S. Sun, and L. Qiao, "Photocatalytic degradation and kinetics of Orange G using nanosized $\mathrm{Sn}(\mathrm{IV}) / \mathrm{TiO}_{2} / \mathrm{AC}$ photocatalyst," Journal of Molecular Catalysis A, vol. 260, no. 1-2, pp. 241-246, 2006.

[123] J. Wang, W. Sun, Z. Zhang et al., "Preparation of Fedoped mixed crystal $\mathrm{TiO}_{2}$ catalyst and investigation of its sonocatalytic activity during degradation of azo fuchsine under ultrasonic irradiation," Journal of Colloid and Interface Science, vol. 320, no. 1, pp. 202-209, 2008.

[124] N. Sobana, K. Selvam, and M. Swaminathan, "Optimization of photocatalytic degradation conditions of Direct Red 23 using nano-Ag doped $\mathrm{TiO}_{2}$," Separation and Purification Technology, vol. 62, no. 3, pp. 648-653, 2008. 

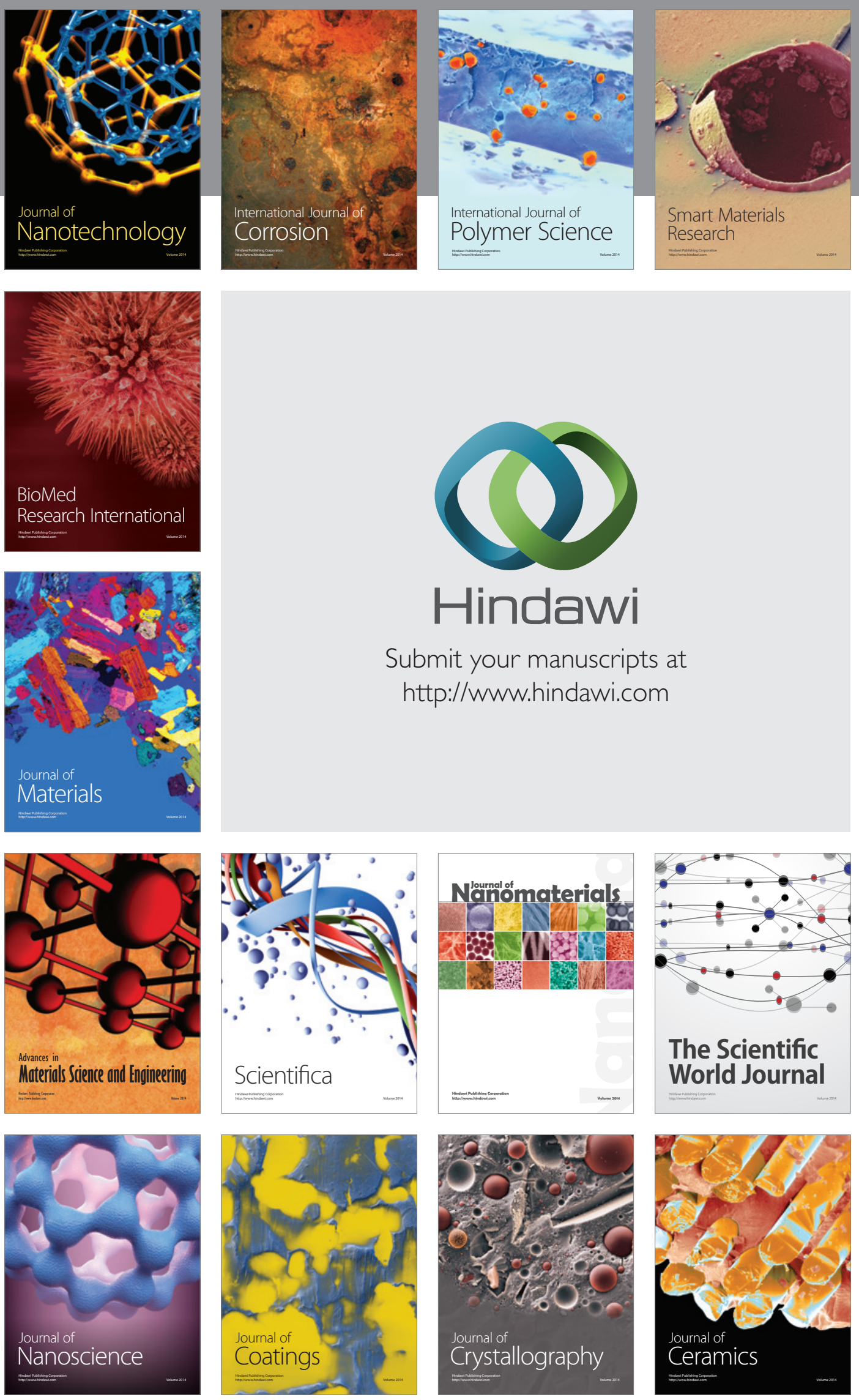

The Scientific World Journal

Submit your manuscripts at

http://www.hindawi.com

\section{World Journal}

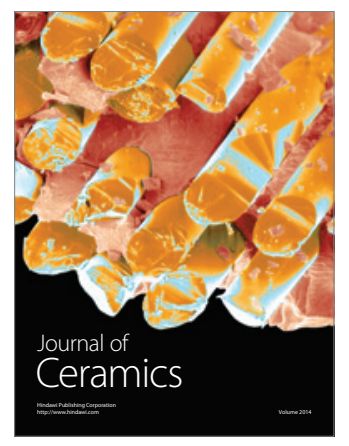

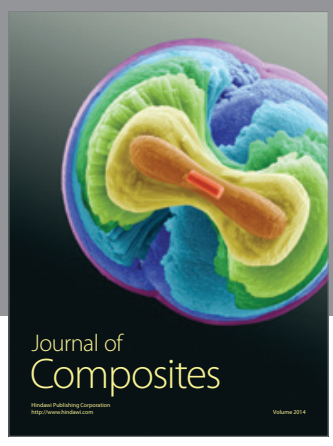
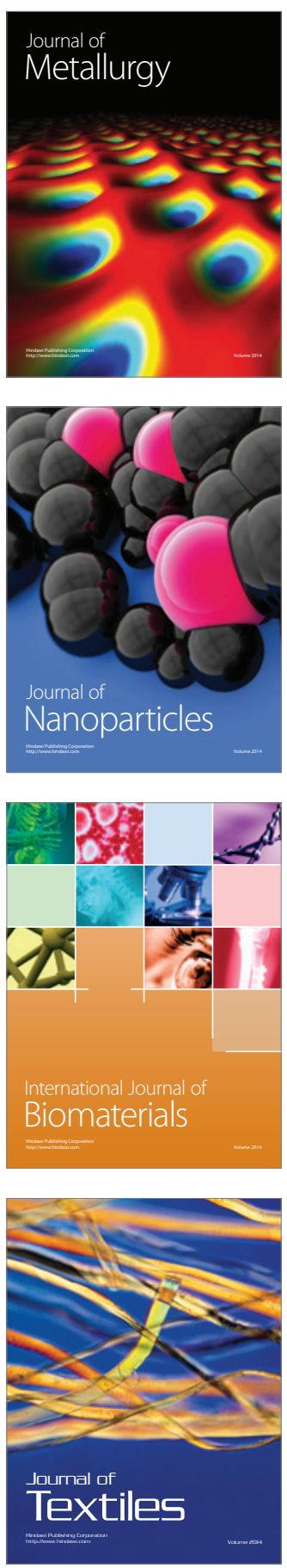